\title{
Uterotonic Plants and their Bioactive Constituents
}

Authors

Affiliations
Christian W. Gruber ${ }^{1}$, Margaret O’Brien ${ }^{2}$

${ }^{1}$ Department of Pharmacognosy, University of Vienna, Vienna, Austria

${ }^{2}$ National Centre for Biomedical and Engineering Science, Orbsen Building, National University of Ireland Galway,

Galway, Ireland
Key words

- women's health

- gynaecology

- labour

- myometrial smooth muscle

oxytocin

- cyclotides

- plants received June 1, 2010

revised July 28,2010

accepted August 5, 2010

\section{Bibliography}

Dol http://dx.doi.org/

10.1055/s-0030-1250317

Published online September 15,

2010

Planta Med 2011; 77: 207-220

(c) Georg Thieme Verlag KG

Stuttgart · New York .

ISSN 0032-0943

Correspondence

\section{Dr. Christian W. Gruber}

Department of Pharmacognosy

University of Vienna

Althanstrasse 14

1090 Vienna

Austria

Phone: + 431427755262

Fax: +43142779552

christian.gruber@univie.ac.at

\section{Abstract}

$\nabla$

Abnormalities in the process of uterine muscle contractility during pregnancy and birth can have major clinical implications, including preterm labour, which is the single largest cause of maternal and prenatal mortality in the Western world and a major contributor to childhood developmental problems. In contrast, induction of labour may be necessary in certain conditions. Currently used interventional therapies to suppress (tocolytic agents) or to induce (uterotonic agents) uterine contractions lack potency and/or selectivity and can have harmful side effects for mother and baby. Nature's diversity has always been, and still is, one of the biggest resources of therapeutic lead compounds. Many natural products exhibit biological activity against unrelated targets, thus providing researchers with starting points for drug development. In this review we will provide an overview of uterine muscle physiology, describe currently available biological screening procedures for testing of uterotonic plant compounds and will summarise traditionally-used uterotonic plants, their active components and

\section{Introduction \\ $\nabla$}

Traditional medicine relies on the use of certain herbal plants and other remedies for beneficial effects during pregnancy, to induce labour, in the removal of retained placenta and management of post-partum bleeding. However, some of these medicines have harmful side effects and when taken in large quantities can lead to the death of the unborn baby and/or uterine rupture, and other longer term effects on the mother or baby. Most often the biological effects elicited by these remedies are due to biomolecules (small chemicals, peptides or proteins) that primarily act on the uterus. The nature of these actions may in- their mechanisms, primarily focusing on uterotonic active circular plant peptides called cyclotides. Finally we will comment on the discovery of novel cyclotide-producing plant species and the possibility for the development of novel plant-derived uterotonic and tocolytic drugs.

$\begin{array}{ll}\text { Abbreviations } \\ \nabla \\ \text { AC: } & \text { adenylyl cyclase } \\ \text { CCK: } & \text { cyclic cystine knot } \\ \text { COX-2: } & \text { cyclooxygenase-2 } \\ \text { CRH: } & \text { corticotropin-releasing hormone } \\ \text { GPCR: } & \text { G-protein coupled receptor } \\ \text { IL: } & \text { interleukin } \\ \text { IP }: & \text { D-myoinositol 1,4,5-triphosphate } \\ \text { MLC: } & \text { myosin light chain } \\ \text { NF: } & \text { nuclear factor } \\ \text { OT: } & \text { oxytocin } \\ \text { PL: } & \text { phospholipase } \\ \text { R: } & \text { receptor } \\ \text { SFE: } & \text { supercritical fluid extraction } \\ \text { SR: } & \text { sarcoplasmic reticulum } \\ \text { TNF: } & \text { tumour necrosis factor }\end{array}$

volve the modulation of uterine contractions at labour, resulting in either the stimulation ("uterotonic") or inhibition ("tocolytic") of myometrial muscle contractions. In this review we will provide an overview of uterotonic herbs and their active constituents. This includes traditionally-used as well as recently identified plants or isolated plant compounds, which have reportedly shown uterine smooth muscle-stimulating activities. Furthermore we will give a brief outline of available uterotonic assay systems and provide a list of uterotonic plants, their bioactive ingredients and their mechanism of action on the uterus. Our focus will be on the description of recently identified cyclotide peptides, mainly found in plants 
from the Rubiaceae and Violaceae families, which have shown to be uterotonic agents. We will begin this article with a thorough description of uterine physiology and molecular details of uterine smooth muscle contractility.

\section{Uterine Muscle Physiology}

$\nabla$

\section{Biology of the uterus}

The uterus is the central organ of reproduction. It is a thick, pearshaped, muscular organ approximately, $7 \mathrm{~cm}$ long, and $4-5 \mathrm{~cm}$ wide at its widest point. It is divided functionally and morphologically into three sections, namely the cervix, the isthmus and the main body of the uterus (corpus uteri) [1].

The myometrium is the middle muscular layer that makes up the major proportion of the uterine body. Myometrial smooth muscle is arranged in undefined layers and contractile forces can occur in any direction enabling the uterus to assume virtually any shape. Through growth and stretch during pregnancy, the myometrium provides the protective environment for the developing foetus. Then with the onset of labour it contracts rhythmically to expel the foetus and placenta. Smooth muscle fibres are composed of spindle-shaped cells, each with one centrally located nucleus. Typically, they have a diameter of $2-10 \mu \mathrm{m}$ and a length of several hundred $\mu \mathrm{m}$ [2]. Smooth muscle cells are embedded in an extracellular matrix composed principally of collagen fibres, which facilitate the transmission of contractile forces generated by individual cells. They are organised into sheets of closely opposed fibres, oriented at right angles to each other. These sheets form two distinct layers, the "longitudinal layer", which consists of a network of bundles of smooth muscle cells generally oriented in the long axis of the organ, and the "circular layer", in which the fibres are arranged concentrically around the longitudinal axis of the organ [3]. Contraction of the longitudinal layer causes the organ to dilate and shorten, whereas contraction of the circular layer causes the organ to elongate; thus alternating contraction and relaxation of these layers enables the uterus to expel its contents at birth [2].

\section{Uterine muscle contractility}

The onset of labour is facilitated by phasic myometrial contractions that are driven by the development of action potentials across the plasma membrane, resulting from a transient increase in the cytosolic free $\mathrm{Ca}^{2+}$ concentration [4]. In this case (calciumdependent smooth muscle contraction), calcium is released from the sarcoplasmic reticulum (SR) and from extracellular stores through voltage-gated calcium channels. Therefore smooth muscle contractility by different agonists or by electrical depolarisation results in a rapid increase in $\left[\mathrm{Ca}^{2+}\right]_{\mathrm{i}}[5] . \mathrm{Ca}^{2+}$ binds to four binding sites of calmodulin causing a conformational change allowing the calmodulin-calcium complex to interact with inactive myosin light chain kinase (MLCK), thus activating its enzymatic properties [6]. MLCK rapidly phosphorylates the $20 \mathrm{kDa}$ myosin light chain (MLC). Phosphorylation of MLC leads to conformational changes in the myosin head that causes actin activation of myosin ATPase, resulting in force generation and/or shortening (contraction) of the muscle fibres [7]. Dephosphorylation of MLC by MLC phosphatase (MLCP) results in smooth muscle relaxation [8]. Myometrial contraction is influenced by a variety of physiological mechanisms involving intracellular signalling, calcium, ion channels, cell membrane receptors, peptides, metabolic and neuronal factors and hormones [9]. The most important factors are described below and are summarised in $\bullet$ Fig. 1 .

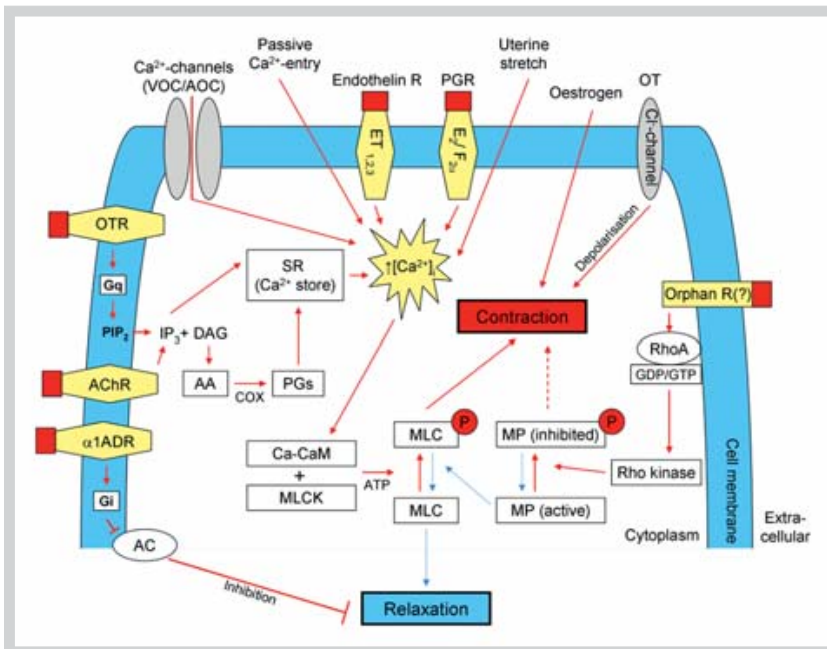

Fig. 1 Uterine contraction signalling pathways. Uterotonic pathways (red arrows) - Myometrial contraction and relaxation result from the phosphorylation or dephosphorylation of myosin light chains (MLC), respectively. Phosphorylation, by the enzyme myosin light chain kinase (MLCK), in the presence of adenosine triphosphate (ATP), is regulated by intracellular calcium concentrations $\left(\left[\mathrm{Ca}^{2+}\right]_{\mathrm{i}}\right)$, in conjunction with the intermediate protein calmodulin (CaM), which together form the calcium-calmodulin (Ca-CaM) complex. Calcium channels (voltage and agonist operated channels; VOC) $A O C)$, membrane endothelin (ET) receptors $\left(E T_{1}, E T_{2}, E T_{3}\right)$, passive entry, membrane prostaglandin $(P G)$ receptors $\left(E_{2}, F_{2 \alpha}\right)$ and stretch, all facilitate an increase in intracellular $\mathrm{Ca}^{2+}$ concentration $\left(\uparrow\left[\mathrm{Ca}^{2+}\right]_{\mathrm{i}}\right)$ and result in smooth muscle contraction. Agonist-mediated activation of membrane acetylcholine (ACh) and oxytocin (OT) receptors stimulate the production of the second messenger D-myoinositol 1,4,5-triphosphate $\left(\mathrm{IP}_{3}\right)$, the latter through the action of the enzyme phospholipase $C$ (coupled to the OTR by the G-protein $[\mathrm{Gq}]$ ) on the plasma membrane constituent phosphatidylinositol 4,5-bisphosphate $\left(\mathrm{PIP}_{2}\right)$. IP $\mathrm{I}_{3}$ releases $\mathrm{Ca}^{2+}$ from the sarcoplasmic reticulum $(\mathrm{SR})$ thus increasing $\left[\mathrm{Ca}^{2+}\right]_{i}$ and resulting in cell contraction. A byproduct of $\mathrm{IP}_{3}$ synthesis, the second messenger diacylglycerol (DAG) might promote cell contraction via intracellular PG synthesis from arachidonic acid (AA) by cyclooxygenase (COX) enzymes. The steroid hormone oestrogen promotes cellular contractility by upregulating COX enzymes, particularly the COX-2 isoform. The active isoform of myosin phosphatase (MP) dephosphorylates MLC, promoting cell relaxation. Receptor-agonist binding and the formation or upregulation of intracellular RhoA or Rho kinase could result in a shift in the equilibrium of intracellular MP in the direction of the inactive isoform, resulting in enhanced cell contraction, i.e., calcium sensitisation. Agonist binding of the $\alpha_{1}$ adrenergic receptor ( $\left.\alpha 1 A D R\right)$ stimulates inhibitory G-proteins $\left(G_{\mathrm{i}}\right)$, which inactivate the adenylyl cyclase (AC) mediated production of cAMP from ATP. CAMP results in cell relaxation in many ways, including inhibition of MLCK and the efflux of $\left[\mathrm{Ca}^{2+}\right]_{i}$ through sodium/ calcium $\left(\mathrm{Na}^{+} / \mathrm{Ca}^{2+}\right)$ exchanger channels. Chloride $\left(\mathrm{Cl}^{-}\right)$channels, which might be activated by OT, exert their uterotonic effect by depolarisation of the smooth muscle cell membrane. Uterorelaxant pathways are indicated by blue arrows. Figure was adapted with modifications from [154].

\section{G-proteins and G-protein coupled receptors involved} in myometrial contraction

G-protein coupled receptor (GPCR) activation can result in profound stimulatory or inhibitory effects on myometrial contraction. For example, receptors coupled to $\mathrm{G} \alpha_{\mathrm{q}}$, e.g., oxytocin (OT) receptors, endothelin receptors, prostaglandin (PG) receptors $E$ (subtype $\mathrm{EP}_{1}$ ), $\mathrm{F}(\mathrm{FP})$ and thromboxane $\mathrm{A}_{1}$ receptor, stimulate contractility by activating the phospholipase C (PLC)-Ca ${ }^{2+}$ pathway; receptors coupled to $\mathrm{G} \alpha_{s}$, e.g., $\beta_{2}$-adrenoceptors as well as $\mathrm{PG}$ receptors $\mathrm{DP}, \mathrm{EP}_{2}$ and IP relax the uterus by stimulating adenylyl cyclase $(A C)$ and increase myometrial cAMP levels; while 
receptors coupled to $\mathrm{G} \alpha_{\mathrm{i}}$, e.g., $\alpha_{2}$-adrenoceptors, muscarinic receptors, potentiate contractility by inhibiting cAMP production [10]. Activated G-protein subunits trigger many effectors, which can then regulate ion channel activity [11] - directly or indirectly, by stimulating/inhibiting phosphorylation pathways, initiating intracellular cascades leading to elevation of cytosolic $\mathrm{Ca}^{2+}$ or cAMP, or by generating various lipid-derived compounds that can alter channel activity [12]. $\mathrm{K}_{\mathrm{v}}$, KATP and Maxi-K channels are all potential targets for direct regulation by GPCRs or the second messengers generated by GPCR-linked pathways $[9,10,12]$. In the following paragraphs we will provide more detail on the myometrial effects of OT, PGs and corticotrophin releasing hormone (CRH).

Oxytocin: OT is a potent uterotonic nonapeptide hormone [13], which is known to act both directly and indirectly to stimulate uterine smooth muscle contraction and is widely used for the artificial induction of labour [14]. It circulates as a free peptide in the bloodstream and, as with all hypothalamic hormones, is released discontinuously in a pulsatile fashion [15]. Its release into the bloodstream can be stimulated by the administration of PGs [16] or dopamine [17]. OT mediates most of its effects through the OT receptor (OTR), which is a member of the OT/vasopressin GPCR family [18] of the $G \alpha_{\mathrm{q}}$ subfamily, to stimulate PLC activity [19]. OT induces contraction by elevating intracellular calcium concentration $\left(\left[\mathrm{Ca}^{2+}\right]_{\mathrm{i}}\right)$, first by PLC-mediated D-myoinositol 1,4,5-triphosphate $\left(\mathrm{IP}_{3}\right)$ induced release of $\mathrm{Ca}^{2+}$ from internal stores [20-22], followed by influx of extracellular $\mathrm{Ca}^{2+}$ via voltage- and receptor-operated calcium channels $[20,23]$ or capacitative calcium entry [24]. OT also stimulates an increase in cytoplasmic phospholipase $\mathrm{A}_{2}\left(\mathrm{PLA}_{2}\right)$ activity and induces cyclooxygenase-2 (COX-2), the two major enzymes of PG biosynthesis [25]. OTR mRNA expression is influenced by several factors, including hormones, certain cytokines and transcription factors [18].

Prostaglandins: PGs are members of the eicosanoid family of proteins. They are lipid mediators produced by the uterus, foetal membranes and the placenta and are capable of modulating uterine contractions [26] and have been used in pregnancy for a variety of treatments [27]. When PG receptors are bound by their specific ligand, distinct intracellular pathways are activated, linked to the contractile $\left(\mathrm{EP}_{1}, \mathrm{EP}_{3}, \mathrm{FP}\right.$, thromboxane) or the relaxant $\left(\mathrm{EP}_{2}, \mathrm{EP}_{4}, \mathrm{IP}, \mathrm{DP}\right)$ receptor isoforms [28]. $\mathrm{PGE}_{2}$ and $\mathrm{PGF}_{2 \alpha}$ play important roles in myometrial contraction, cervical ripening and the initiation of parturition in humans [29]. The contractile effect of PGs is based on their ability to mobilise calcium and inhibit AC activity. $\mathrm{PGE}_{1}$ and $\mathrm{PGF}_{2 \alpha}$ stimulate $\mathrm{Ca}^{2+}$ release from the $\mathrm{SR}$ of the myometrial cells [30]. PGs exert their effects through a number of GPCRs [31]. Binding of $\mathrm{PGF}_{2 \alpha}$ to its contractile receptor stimulates G-protein $\left(\mathrm{G}_{\mathrm{q} / 11}\right)$ activation of PLC and PLA $\mathrm{A}_{2}$, which stimulate production of $\mathrm{IP}_{3}$ and intracellular calcium release [32,33]. The released $\mathrm{IP}_{3}$ mobilises $\left[\mathrm{Ca}^{2+}\right]_{\mathrm{i}}$ from the $\mathrm{SR}$, resulting in increased uterine contractility. $\mathrm{PGE}_{2}$ exerts a dose-dependent increase in $\left[\mathrm{Ca}^{2+}\right]_{\mathrm{i}}$ mediated through $\mathrm{G}_{\mathrm{q}}$ [34]. The effects of $\mathrm{PGE}_{2}$ and $\mathrm{PGF}_{2 \alpha}$ are mediated mainly through EP and FP receptor subtypes, respectively [35]. PGs have both direct and indirect effects on myometrial contractions, further increase uterine sensitivity to uterotonic agents, synchronise myometrial contractions [36,37] and alter hormone synthesis [38]. Additionally, $\mathrm{PG}$ receptors $\mathrm{EP}_{2}$ and $\mathrm{EP}_{4}$ are responsible for smooth muscle relaxation and uterine quiescence [28].

Corticotropin-releasing hormone: $\mathrm{CRH}$ is a 41 amino acid polypeptide which mainly functions as as the hypothalamic regulator of the mammalian stress response. CRH stimulates adrenocorticotrophin release from the anterior pituitary gland and consequently cortisol secretion from the foetal adrenal gland [39]. CRH action is mediated by multiple receptor subtypes with differential patterns of expression depending on the state of the myometrium (non-pregnant or pregnant - term/preterm) [40]. During most of pregnancy CRH, acting via CRH receptor subtypes coupled to AC, plays a "protective" role by promoting myometrial quiescence via generation of CAMP and cGMP, and upregulation of nitric oxide synthase expression [41]. CRH may also prevent contractions by inhibiting production of $\mathrm{PGE}_{2}$ [42]. During the third trimester, $\mathrm{CRH}$ derived from the placenta is secreted into the maternal circulation in large amounts [40]. At term, myometrial contractility is enhanced by a complex series of molecular switches, involving the upregulation of OTR expression and cross-talk between the OT and CRH receptors [43]. OT action is mediated via pertussis toxin-sensitive G-proteins, which directly inhibit $A C$ and via activation of protein kinase $C$, phosphorylate specific CRH receptor subtypes, leading to desensitisation [42]. Thus, $\mathrm{CRH}$ receptor binding affinity for $\mathrm{CRH}$ is lowered, causing a reduction in intracellular cAMP levels, which results in a shift in the intracellular microenvironment in favour of contractility [41]. The function of CRH at term now changes, as it is able to enhance the contractile response of the myometrium, via distinct lower-affinity $\mathrm{CRH}$ receptor subtypes, through stimulation of prostaglandin $\mathrm{PGF}_{2 \alpha}$ and $\mathrm{PGE}_{2}$ production [44]. CRH also stimulates placental release of OT [39]. Another function of CRH at term is the stimulation of cortisol and the production of dehydro-epi-androstenedione, the precursor to oestradiol from the foetal adrenal gland [45].

\section{Steroid hormones involved in myometrial contraction}

Oestrogens: Oestrogens comprise a group of steroid hormones, including oestradiol, oestriol and oestrone. They are synthesised mainly in the ovaries, although small amounts are also produced in the adrenal cortex and the placenta. During pregnancy oestrogens are responsible for uterine growth which ceases at the end of pregnancy, the consequent increasing stretch of the uterine wall stimulates contraction [46]. In human nonpregnant myometrium, the inhibitory action of oestrogens is achieved through inhibition of receptor-operated calcium channels and possibly also the release of intracellular calcium [47]. Oestrogen is also linked to an increase in PLC isozyme expression in uterine smooth muscle [48] and has been shown to up-regulate OTR concentration in myometrial cells [49]. Most, if not all, of the actions of oestrogens are mediated by interaction with the specific nuclear receptors, ER $\alpha$ and $\operatorname{ER} \beta[50,51]$.

Progesterone: Progesterone is another steroid hormone, primarily produced by the corpus luteum of the ovary, but also by the placenta that prepares the lining of the uterus for implantation of a fertilised ovum and maintains this state during pregnancy [52]. It is a pro-pregnancy hormone and negatively regulates many of the labour associated proteins. It supports uterine quiescence by stimulating a variety of relaxant mechanisms, such as the nitric oxide system, by suppressing myometrial responsiveness to uterotonic agents, primarily by inhibiting gap junctions [53]. It functionally opposes oestrogen action. In humans a functional withdrawal of progesterone precedes labour onset, the switch from the growth phase of pregnancy to the uterine stretch observed at the end of pregnancy due to pressure on the uterine wall from the foetus appears to be regulated by progesterone. Progesterone withdrawal increases the attachment of myocytes 
to the intercellular matrix through integrins, and this process leads to the activation of mitogen-associated protein kinase and increases contractility [46]. Progesterone mediates its effects through its receptors, members of the nuclear receptor subfamily PR-A, PR-B and PR-C isoforms [54].

\section{Inflammatory signals in labour and myometrial contraction}

Many of the biochemical events involved in parturition resemble an inflammatory reaction, with growing evidence pointing to a crucial role for pro-inflammatory cytokines and PGs in labour [55]. This may in part be due to increased surfactant protein production in the foetal lung. Firstly, cortisol production in the foetal adrenal glands increases due to increased placental CRH production [56]. This results in foetal lung maturation with an increase in surfactant proteins which are critical for lung function. The surfactant proteins enter the amniotic fluid where they have macrophage activating properties $[46,57]$. In the mouse, surfactant protein A activates amniotic fluid macrophages, and these cells play an active role in labour onset [58]. In humans it is postulated that the surfactant proteins may stimulate the inflammation observed in the foetal membranes, cervix and myometrium at the time of labour [46]. Parturition is characterised by an influx of inflammatory cells into the maternal tissues, placenta and foetal membranes $[59,60]$ and increased expression of proinflammatory cytokines in both preterm and term labour. Elevated levels of interleukin (IL)-1 $\beta$, IL-6 and tumour necrosis factor TNF $\alpha$ are detected in amniotic fluid $[61,62]$, myometrium and choriodecidua [59,63] and cervicovaginal secretions [64]. These pro-inflammatory cytokines are thought to contribute to labour onset by stimulating the production of IL-8 and PGs. IL-8 acts in the formation of the lower uterine segment in late pregnancy and in mediating the inflammatory infiltrate seen in myometrium during labour [55]. IL-8 expression is induced by IL-1 $\beta$, TNF $\alpha$, lipopolysaccharide and phorbol esters. It has promoter binding sites for nuclear factor NF-KB, AP-1 and C/EBP [65]. PGs, in turn, cause cervical ripening and foetal membrane remodelling [66]. Both term and preterm labour are also associated with NF-KB activation [58], which, in turn, increases expression of genes promoting myometrial contractility, including the $\mathrm{PGF}_{2 \alpha}$ receptor [66], the gap junction protein connexin 43 [67], the OTR [68] and COX-2 [69]. Following the description of myometrial signalling and uterine contractility pathways, we will provide and overview of uterotonic test systems.

\section{Biological Screening Assays for Uterotonic Agents $\nabla$}

Suitable models are essential to study the processes involved in myometrial contraction and the agents which mediate these responses. The use of in vivo studies is not ideal as the process of labour differs amongst animals, and human parturition is distinct from that of other mammals, which limits the use of animal models [70]. Isolated organ bath assays are the classical pharmacological screening tool for isometric recordings to assess concentration-response relationships in contractile tissue (for overview see [71]). The organ bath assay permits complex responses to be studied where tissue responses are controlled by several physiological parameters. Myometrial tissue strips have been used for tissue bath experiments, but ethical constraints and difficulties in obtaining human samples limit the use of this system. Alternatively, electrophysiology studies using the well known patch- clamp technique can be conducted to measure responsiveness of contractile tissue. The patch-clamp technique is a method to study the electrophysiological properties of biological membranes (for overview see [72]). In addition to these classical pharmacological and electrophysiological assays, there are two recently developed techniques to study the biological effects of uterotonic agents, which will be described in the following sections.

\section{Supercritical fluid extraction coupled online to uterotonic assays}

Supercritical fluid extraction (SFE) is the process of separating components from solid or liquid matrices using supercritical fluids as extracting solvent. The technique's origin is as a large-scale process used in the food and pharmaceutical industry and for environmental analysis $[73,74]$. It is used to purify required compounds from mixtures, such as the collection of essential oils from plants, or to extract unwanted compounds or contaminants from a product. More frequently it is being used as a sample preparation and analytical method for the extraction of various natural products [73].

A modified and optimised SFE method has been used by Sewram and colleagues to extract and analyse several plants for their uterotonic activity $[75,76]$. The SFE extracted plant fractions are coupled online to the uterotonic bioassay, i.e., isolated uterine muscle strips (guinea pig) that are placed in an organ bath chamber, which is connected to the extraction chamber. This method also allowed the pretreatment of muscle contracting stimulants (e.g., acetylcholine or bradykinin) or blockers (e.g., HOE 140 or atropine) to further analyse possible mechanisms of uterine contractility [76]. The described approach has been validated by testing aqueous extracts of Clivia miniata (Lindl.) Regel [75]. This plant has shown comparable uterotonic activity in an independent study using an isolated organ bath [77]. Although the uterotonic bioassay used in this set-up is different from that described previously (organ bath methodology), the SFE coupled online to uterotonic assays offers the advantages of reduced extraction time, increased sensitivity, easier analyte fractionation and enhanced reproducibility due to protection of environmental influences of the extraction procedure and bioassay measurements [76].

\section{Collagen contractility assay}

Collagen is an ideal substrate for uterotonic assays as it forms the main component of the extracellular matrix in vivo and it does not cause cytotoxicity. Bell et al. described the formation of a "tissue-like structure" produced by seeding fibroblasts in a collagen matrix and collagen lattices are now widely used as in vitro models for many diverse purposes [78]. Furthermore, preparation of lattices can be altered to best mimic the tissue of interest. Using an isolated cell system allows the study of effects on cells by individual stimuli, without interference from other sources. Type 1 collagen is widely available, so studies are not restricted by sample number. With tissue strip experiments, inherent differences exist between myometrial samples; however, with this collagen contractility system a uniform solution of cells and collagen is used, ensuring that all replicates are comparable. Examples of the utilisation of the collagen contractility assay on uterine cells include: (i) the monitoring of the effects of endothelin-1 on human myometrially-derived smooth muscle cells [79], (ii) determination of the effect of OT and its inhibitors on two human myometrial cell lines, i.e., telomerase-immortalised human myometrial cells (hTERT-C3) and a cell line derived from primary culture 
of human myometrial cells [80], (iii) study on primary human uterine smooth muscle cells (hUtSMCs) that demonstrated increases in gel contraction with OT, KCL and TNF [81] and (iv) the modulation of primary hUtSMC and hTERT-HM myometrial smooth muscle cell contractility by thrombin, the ROCK inhibitor Y-27632, TNF $\alpha$ and the prostaglandin inhibitor indomethacin [82-84]. Therefore, the collagen contractility assay is an effective and robust in vitro model of human myometrium [79,80,82-84] (O Fig. 2).

In particular, the assay allows the determination of the biological effects of various unknown (plant) compounds on uterine smooth muscle contractility. To determine the biochemical pathways involved in the modulation of myometrial contractility some clinically used inhibitors may be applied to the assay, such as indomethacin (a non-selective PG receptor inhibitor), COX-2 inhibitors, atosiban (OTR inhibitor), nifedipine (calcium channel blocker), ritodrine and terbutaline $\left(\beta_{2}\right.$-adrenergic receptor agonists), salbutamol ( $\beta_{2}$-sympathomimetics) and Y-27632 (Rho kinase inhibitor). Furthermore, this contractility assay set-up allows investigations at the molecular biology level by isolating RNA and protein from the cells in the collagen matrix, which has been previously demonstrated [82]. RT-PCR and Western blotting techniques may be utilised to monitor gene and protein expression changes.

Having presented a thorough description of uterine physiology, the molecular mechanisms of myometrial muscle contractility and currently available uterine contractility assay systems, we will now provide an overview of traditionally-used and recently identified uterotonic plants and their bioactive constituents.

\section{Uterotonic Plants and their Bioactive Constituents \\ $\nabla$}

The use of herbal medicine to alleviate problems associated with gynaecological conditions of menstruation and menopause, to support health during pregnancy and to facilitate childbirth is common amongst many traditional cultures. Detailed ethnobotanical surveys have been reported for several native communities around the world and many traditionally-used plants or remedies have been identified.

\section{Traditionally used plants in gynaecology}

Traditional cultures rely on the beneficial effects of herbal remedies during pregnancy, birth and post-partum care. The knowledge and the correct use of these natural medicines has been acquired and improved over many generations. Documentation of traditional knowledge of medicinal plants is crucial, since it provides chemists and pharmacologists with starting points for "targeted" analysis, discovery of novel remedies and natural drugs for the treatment of pregnancy and birth-related problems.

Ethnobotanical studies with the aim to identify and document the native use of plants to treat gynaecological health issues have been reported, e.g., for Argentina [85], China [86,87], Dominican Republic [88], Honduras [89], Indonesia [90], Laos [91], Mexico [92], Tonga [93], Vanuatu [94], Thailand [95] and many others. Some studies provide initial pharmacological characterisation, e.g., preliminary biological testing of uterotonic effects of 28 plants from Ethiopia [96], identification of active compounds of 12 plant species from Guatemala that bind to oestrogen and/or serotonin receptors [97] and identification of at least five uterotonic plant species from South Africa (see below) [98].

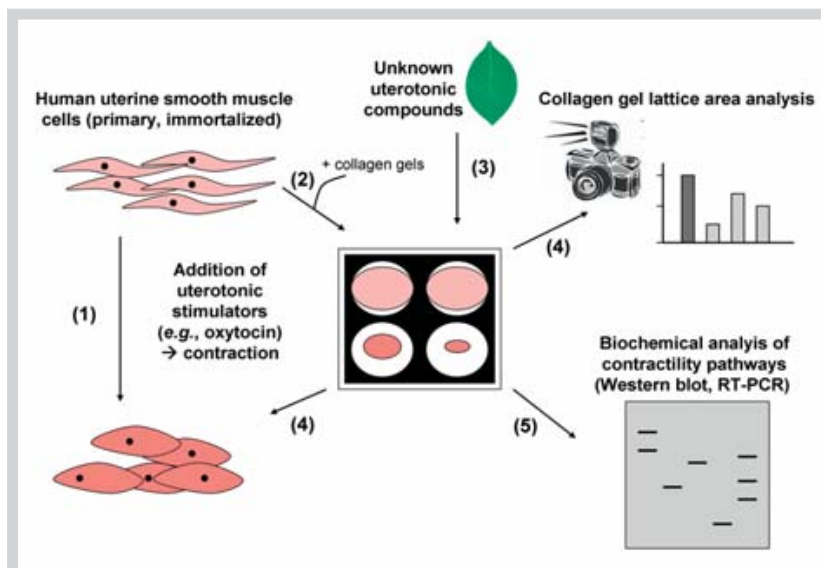

Fig. 2 Overview of collagen gel uterine contractility assay. Human myometrial smooth muscle cell lines (e.g., telomerase-immortalised human myometrial cells or cell lines derived from a primary culture of human myometrial cells) contract in the presence of uterotonic stimulators, such as oxytocin (1). Collagen gels will be seeded in culture dishes with an appropriate amount of myometrial cells per well (based on the technique described by Fitzgibbon et al. [83]) (2). Cells in collagen gels will be allowed to equilibrate overnight in serum free medium. Various plant compounds of interest will be added to the serum free media and gels released from the culture dishes (3). The effect of collagen contractility will be monitored and quantified over time. The effect of concentration gradients of the various compounds on contractility will also be evaluated by this method (4). To determine which biochemical pathways are involved in the modulation of myometrial contractility various compounds that act as inhibitors of myometrial contractility pathways may be added to the collagen gel mix, prior to treatment of unknown plant compounds and gel release. Further investigations at the molecular biology level by isolating RNA and protein from the cells in collagen may be performed (5).

The use of plant remedies is also documented in native Northern America, where herbal medicines are taken as tonics during pregnancy to prepare for labour (e.g., raspberry leaf, partridge berry and stinging nettle), to prevent miscarriage (e.g., black haw and false unicorn) and to induce labour (blue cohosh, black cohosh and beth root) [99]. Preparations of black cohosh root (Actaea racemosa [Nutt.] L.), Goldenseal root (Hydrastis canadensis L.) and Chaste tree fruits (Vitex agnus-castus L.) are listed in the U.S. Pharmacopoeia and are available as dietary supplements to be used for premenstrual stress syndrome, as emmenagogue agents and for gynaecological problems. Other traditionally used medicines, such as raspberry leaves (Rubus idaeus L.) [100], castor oil (Ricinus communis L.) [101] and cotton bark root (Gossypium hirsutum L.) [102] are again receiving attention from midwives for applications during pregnancy and labour $[103,104]$.

Infusions of various plant species have been used from early times to treat ailments of pregnant women in traditional medicine of central European countries, e.g., Austrian traditional medicine [105] as well as in some countries of the Balkans, e.g., Bosnian traditional medicine [106]. For example, German chamomile (Matricaria recutita L.), small-leaved lime (Tilia cordata Mill.) and large-leaved lime (Tilia platyphyllos Scop.) as well as aerial parts of marjoram (Origanum majorana L.) and fruits of caraway (Carum carvi L.) have been used to ease the birthing process. 


\section{Uterotonic active plants}

There is a vast array of information available on traditionally used herbs to treat gynaecological problems. The medicinal properties of many of these plants have not yet been studied in molecular detail but it is clear that they may affect a number of different physiological targets and pathways in the female body. The focus of this review is on uterotonic plants and we will briefly provide the selection criteria of plants listed and described in this article. There are at least four categories of medicinal plants (and their active constituents) that exhibit activity on the uterus:

1. Symptomatic/traditional categorisation: Plants used for the treatment of menstruation problems - dysmenorrhoea (= severe uterus pain during menstruation) or menopause symptoms, herbal medicines with oxytocic or emmenagogue properties (= herbs that stimulate blood flow in the pelvic area and uterus) used during childbirth and pregnancy and herbal medicines with abortive properties.

2. Biological categorisation: Uterine-stimulating plants (uterotonic) and uterine-inhibiting plants (tocolytic).

3. Pharmacological categorisation: Agonists or antagonists (full, partial, inverse) of uterine contractility-related pathways.

4. Chemical categorisation: Small chemical compounds, peptides or proteins.

We have included plants, plant extracts or pure plant-derived compounds that have demonstrated the stimulation of uterine contractility (uterotonic) in vivo or in vitro. Plants that indirectly elicit effects on the uterus, such as the increased production of uterotonic substances (e.g., observed upon the administration of Artemisia monosperma in rats [107]) or the upregulation of PG synthesis, have specifically not been included. We have also not included substances that inhibit uterine contractility (tocolytic agents). Furthermore, any pure plant-derived uterotonic compounds that are already marketed drugs (or in clinical trials) as stimulants of uterine contractility, have not been included. Following these criteria, we have surveyed the literature for uterotonic plants and active plant compounds, which are listed in $\odot$ Table 1.

\section{Uterotonic plant compounds: the discovery} and application of cyclotides

Upon compilation of the comprehensive list of uterotonic plants, we will describe uterotonic plant constituents, with an emphasis on the characteristics of the active compounds and their molecular mechanisms. Of particular interest is a class of circular plant peptides, so-called cyclotides, which have recently attracted much attention due to their pharmaceutical and agro-chemical applications.

We have identified and summarised ( $\odot$ Table 1) at least 40 plant species, which appear to have pharmacological evidence for uterotonic activity. It is clear that there are many more uterotonic plants to be discovered, but they have either not yet been tested or do not appear as "uterotonic" in the literature. Although the majority of the plants listed here have been studied thoroughly for their biological activity, their active component(s) or the active principle(s) are not yet fully understood. Examples of isolated and identified uterotonic plant compounds include diterpenes (kaurenoic acid, grandifloric acid and kauradienoic acid; isolated from Montanoa tomentosa and Aspilia mossambicensis) [108-110], phenylpropanoid glucosides (Z-venusol; Gunnera perpensa), [111], heterocyclic aldehydes and fatty acids (5-hydroxymethylfurfural and linoleic acid; Clivia miniata), [75,77], steroidal saponins (pennogenin glycosides; Paris polyphylla)
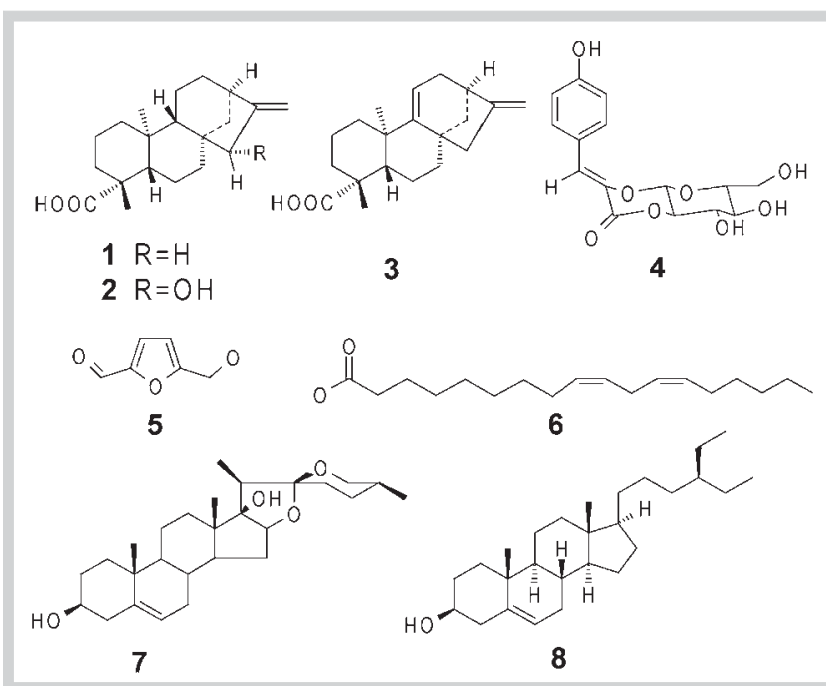

Fig. 3 Structures of uterotonic agents isolated from plants. The chemical structures of kaurenoic acid (1), grandifloric acid (2), kauradienoic acid (3), Z-venusol (4), 5-hydroxymethylfurfural (5), linoleic acid (6), pennogenin (7) (the scaffold for pennogenin glycosides) and $\beta$-sitosterol (8) are shown.

[112], plant sterols ( $\beta$-sitosterol; Punica granatum) [113] ( Fig. 3), and circular polypeptides, so-called cyclotides.

The discovery of the first cyclotide, kalata B1, from the coffee family (Rubiaceae) species Oldenlandia affinis was due to its use in African traditional medicine to accelerate childbirth by uterine stimulation $[114,115]$. Cyclotides are disulfide-rich plant peptides [116] of about 30 amino acids in size and possess the unique structural features of a head-to-tail cyclised backbone and a knotted arrangement of three-disulfide bonds, referred to as a cyclic cystine knot (CCK) motif [116] ( Fig. 4). The compact CCK motif makes cyclotides exceptionally resistant to thermal, chemical or enzymatic degradation [117]. In contrast to secondary plant metabolites, cyclotides are true gene products. Their biosynthesis starts from larger precursor proteins and reportedly involves enzymatic processing $[118,119]$ as well as protein folding events [120].

Lorents Gran studied the pharmacological properties of kalata B1 and found that the peptide induced OT-like uterine muscle contractions in vitro with isolated rat and rabbit uteri and human uterine strips at concentrations of $10-20 \mu \mathrm{g} / \mathrm{mL}$ [115] and this has been confirmed by Gran and colleagues, which reported the uterotonic activity of kalata B1, B2 and B7 at concentrations of $0.5-20 \mu \mathrm{g} / \mathrm{mL}$ [121]. Similar effects were observed in vivo (rat and rabbit) upon peritoneal administration of $\sim 20 \mu \mathrm{g} / \mathrm{kg}$ kalata B1 solution. However, intravenous injections of doses of $\sim 1 \mathrm{mg}$ / $\mathrm{kg}$ were found to be toxic (increased blood pressure and ventricular tachycardia) and eventually lethal (ventricular fibrillation) [115]. It is intriguing to further explore the uterotonic effect of cyclotides in molecular detail, in particular because kalata B1 [122], and other cyclotides (for instance tricyclons A and B from the violet plant Viola tricolor L. [123]), contain sequence and/or structural motifs that are similar to the presumed activity-bearing motifs in the OT peptide $[124,125]$. Aside from their uterotonic activity, cyclotides also exhibit a range of other biological functions, including haemolytic [126], anti-neurotensin [127], anti-HIV [128] cytotoxic [129], anti-bacterial [130], anti-fouling [131] and nematocidal [132]. One of their main natural roles 
Table 1 Uterotonic plants and their active compounds.

\begin{tabular}{|c|c|c|c|c|}
\hline $\begin{array}{l}\text { Plant (scientific name; } \\
\text { family, order) }\end{array}$ & Part of plant, extract & Active compound(s) & Uterotonic principle (mode-of-action) & Refs. \\
\hline $\begin{array}{l}\text { Adenia globosa Engl. (Passi- } \\
\text { floraceae, Malpighiales) }\end{array}$ & Tuber, hot water extract & -1 & $\begin{array}{l}\text { Dose-dependent contraction of the rat uterus; tradi- } \\
\text { tional use: hastening parturition in domestic animals }\end{array}$ & [163] \\
\hline $\begin{array}{l}\text { Agapanthus africanus (L.) } \\
\text { Hoffmg. (Amaryllidaceae, } \\
\text { Asparagales) }\end{array}$ & Leaf, aqueous extract & -1 & $\begin{array}{l}\text { Causes uterine smooth muscle contractions (uterotonic); } \\
\text { agonist activity on uterine muscarinic receptors ( } \mathrm{Ca}^{2+}- \\
\text { channels) and promotion of prostaglandin synthesis }\end{array}$ & [164] \\
\hline $\begin{array}{l}\text { Asclepias fructicosa L. (Apo- } \\
\text { cynaceae, Gentianales) }\end{array}$ & Wood, aqueous extract & -1 & Stimulation of uterine muscle contraction & [76] \\
\hline $\begin{array}{l}\text { Aspilia mossambicensis (Oliv.) } \\
\text { Wild (Asteraceae, Asterales) }\end{array}$ & Leaf, methanol extract & $\begin{array}{l}\text { Kaurenoic and grandiflor- } \\
\text { enic acid (diterpenes) }\end{array}$ & $\begin{array}{l}\text { Potent uterotonic activity; fertility regulator in female } \\
\text { chimpanzees }\end{array}$ & [165] \\
\hline $\begin{array}{l}\text { Bambuseae sp. Kunth ex } \\
\text { Dumort. (Poaceae, Poales) }\end{array}$ & $\begin{array}{l}\text { Green bamboo shoots, } \\
\text { aqueous extract }\end{array}$ & $\begin{array}{l}\text { Serotonin-like } \\
\text { compounds }\end{array}$ & $\begin{array}{l}\text { Induction of uterine contractions; serotonin antagonist } \\
\text { blocked the effect; carboxypeptidase and boiling did } \\
\text { not affect activity }\end{array}$ & [166] \\
\hline $\begin{array}{l}\text { Bidens pilosa L. (Asteraceae, } \\
\text { Asterales) }\end{array}$ & $\begin{array}{l}\text { Leaf, aqueous/metha- } \\
\text { nolic extract }\end{array}$ & -1 & $\begin{array}{l}\text { Increase of uterine motility; strongly augments oxytocin } \\
\text { activity; weak uterine stimulating activity }\end{array}$ & $\begin{array}{l}{[150,} \\
167]\end{array}$ \\
\hline $\begin{array}{l}\text { Bridelia atroviridis Müll. Arg. } \\
\text { (Phyllanthaceae, Malpighiales) }\end{array}$ & Leaf, aqueous extract & -1 & $\begin{array}{l}\text { Induction of uterine contraction (rat) by calcium mobili- } \\
\text { sation from intra- and extracellular compartments and } \\
\text { activation of phospholipase C via G-protein activation }\end{array}$ & [168] \\
\hline $\begin{array}{l}\text { Byrsocarpus coccineus Schum. } \\
\& \text { Thorn. (Connaraceae, } \\
\text { Oxalidales) }\end{array}$ & Leaf, ethanol extract & $\begin{array}{l}\text { Carbohydrates, tannins, } \\
\text { flavonoids, balsams }\end{array}$ & $\begin{array}{l}\text { Repeated treatment with extract enhanced spontane- } \\
\text { ous uterine muscle contractions; possibly involvement } \\
\text { of } \beta \text {-adrenergic receptors }\end{array}$ & [169] \\
\hline $\begin{array}{l}\text { Carica papaya L. (Caricaceae, } \\
\text { Brassicales) }\end{array}$ & Crude papaya latex & -1 & $\begin{array}{l}\text { Induction of spasmodic (tetanic spasms) contraction of } \\
\text { uterus muscle, similar to oxytocin and prostaglandin } F_{2 \alpha}\end{array}$ & [170] \\
\hline $\begin{array}{l}\text { Citrus hystrix DC. (Rutaceae, } \\
\text { Sapindales) }\end{array}$ & $\begin{array}{l}\text { Fruit peel, alcohol and } \\
\text { chloroform extract }\end{array}$ & $\begin{array}{l}\text { Menthol-related } \\
\text { compounds }\end{array}$ & $\begin{array}{l}\text { Stimulation of uterine contractions; increased fre- } \\
\text { quency of contraction; antifertility activity, increase in } \\
\text { uterine weight (when administered simultaneously with } \\
\text { oestrogen) }\end{array}$ & [171] \\
\hline $\begin{array}{l}\text { Clivia miniata (Lindl.) Regel } \\
\text { (Amaryllidaceae, Asparagales) }\end{array}$ & $\begin{array}{l}\text { Leaf and root, aqueous } \\
\text { extract (boiled prepara- } \\
\text { tion) }\end{array}$ & $\begin{array}{l}\text { 5-hydroxymethyl-2-furan- } \\
\text { carbox aldehyde (hetero- } \\
\text { cyclic aldehyde); linoleic } \\
\text { acid (fatty acid) }\end{array}$ & $\begin{array}{l}\text { Uterotonic activity; extracts do not affect the max. } \\
\text { response of oxytocin- or acetylcholine-induced contrac- } \\
\text { tions); increased frequency of spontaneous contrac- } \\
\text { tions; stimulation of uterine contractions by activation } \\
\text { of cholinergic receptors and prostaglandin association }\end{array}$ & $\begin{array}{l}{[75,} \\
77, \\
164]\end{array}$ \\
\hline $\begin{array}{l}\text { Ekebergia capensis Sparrm. } \\
\text { (Meliaceae, Sapindales) }\end{array}$ & Wood, aqueous extract & -1 & $\begin{array}{l}\text { Total extract induced uterine muscle tension followed } \\
\text { by rhythmic activity of increasing amplitude; fraction } \\
\text { produced stimulating action of uterus followed by an } \\
\text { increase in the frequency of contractions }\end{array}$ & {$[76]$} \\
\hline $\begin{array}{l}\text { Eleophorbia drupifera (Thonn.) } \\
\text { Stapf (Euphorbiaceae, Mal- } \\
\text { pighiales) }\end{array}$ & Leaf, hot water extract & -1 & $\begin{array}{l}\text { Extract induced uterine contractions (rat), possibly due } \\
\text { to release of acetylcholine and stimulation of muscarinic } \\
\text { receptors }\end{array}$ & [172] \\
\hline $\begin{array}{l}\text { Erythroxylum coca Lam. (Eryth- } \\
\text { roxylaceae, Malpighiales) }\end{array}$ & Pure substance & Cocaine (alkaloid) & $\begin{array}{l}\text { Cocaine acutely increases contractile activity in myo- } \\
\text { metrium isolated from pregnant women; it augments } \\
\text { spontaneous contractility and the response to adrener- } \\
\text { gic and non-adrenergic contractile agonists }\end{array}$ & [173] \\
\hline $\begin{array}{l}\text { Excoecaria cochinchinensis } \\
\text { Lour. }^{3} \text { (Euphorbiaceae, } \\
\text { Malpighiales) }\end{array}$ & $\begin{array}{l}\text { Latex of leaves, acetone } \\
\text { extract, ethyl acetate } \\
\text { fraction }\end{array}$ & $\begin{array}{l}\text { Daphnane, tigliane } \\
\text { (diterpene esters) }\end{array}$ & Uterotonic activity & [174] \\
\hline $\begin{array}{l}\text { Ficus exasperata Vahl (Mora- } \\
\text { ceae, Rosales) }\end{array}$ & Leaf, aqueous extracts & -1 & $\begin{array}{l}\text { Stimulation of uterine contractility; possibly due to acti- } \\
\text { vation of histamine } \mathrm{H} 1 \text { - and/or } \alpha \text {-adrenergic receptors; } \\
\text { interference with } \mathrm{Ca}^{2+} \text {-channels and/or stimulation of } \\
\text { prostaglandin synthesis }\end{array}$ & [175] \\
\hline $\begin{array}{l}\text { Globimetula braunii (Engler) } \\
\text { Van Tieghem (Loranthaceae, } \\
\text { Santalales) }\end{array}$ & Leaf, aqueous extract & -1 & $\begin{array}{l}\text { Uterotonic affect in rat uterus, probably by agonising } \\
\text { muscarinic receptors }\end{array}$ & [176] \\
\hline $\begin{array}{l}\text { Grewia occidentalis L. (Grewioi- } \\
\text { deae, Malvaceae) }\end{array}$ & Wood, aqueous extract & -1 & $\begin{array}{l}\text { Total extract produced tonic uterine muscle rhythm of } \\
\text { extremely low amplitude and low response (toxic com- } \\
\text { pounds); fraction produced well synchronised response } \\
\text { of regular and rhythmic contractions }\end{array}$ & [76] \\
\hline $\begin{array}{l}\text { Gunnera perpensa L. (Gunnera- } \\
\text { ceae, Gunnerales) }\end{array}$ & $\begin{array}{l}\text { Dry rhizomes, aqueous } \\
\text { extracts (boiled prepara- } \\
\text { tion) }\end{array}$ & $\begin{array}{l}\text { Z-venusol (phenyl-propa- } \\
\text { noid glucoside); pyrogal- } \\
\text { lol, succinic acid, lactic } \\
\text { acid, and trimethyl ether } \\
\text { of ellagic acid glucoside }\end{array}$ & $\begin{array}{l}\text { Extract directly stimulates a contractile response of the } \\
\text { uterine muscle; upon removal of extract the tissue en- } \\
\text { ters a state of continuous spontaneous contractility; } \\
\text { muscarinic receptor system may be involved in the } \\
\text { direct contractile response to the whole plant extract; } \\
\text { pure venusol did not elicited a direct response but a } \\
\text { state of spontaneous contractility }\end{array}$ & $\begin{array}{l}{[111,} \\
177]\end{array}$ \\
\hline
\end{tabular}


Table 1 Uterotonic plants and their active compounds. (continued)

\begin{tabular}{|c|c|c|c|c|}
\hline $\begin{array}{l}\text { Plant (scientific name; } \\
\text { family, order) }\end{array}$ & Part of plant, extract & Active compound(s) & Uterotonic principle (mode-of-action) & Refs. \\
\hline $\begin{array}{l}\text { Harpagophytum procumbens } \\
\text { DC (Pedaliaceae, Lamiales) }\end{array}$ & $\begin{array}{l}\text { Secondary root, aqueous } \\
\text { extract }\end{array}$ & -1 & $\begin{array}{l}\text { Induced dose-dependent and significant contractions of } \\
\text { pregnant and non-pregnant uterine strips (rats) }\end{array}$ & [178] \\
\hline $\begin{array}{l}\text { Heteromorpha trifoliata } \\
\text { (H.L. Wendl.) Eckl. \& Zeyh. } \\
\text { (Apiaceae, Apiales) }\end{array}$ & $\begin{array}{l}\text { Root bark, aqueous } \\
\text { extract }\end{array}$ & -1 & $\begin{array}{l}\text { Uterus contractions (rat), mechanisms of contraction } \\
\text { may involve stimulation of serotonin } \mathrm{HT}_{2} \text { receptors; } \\
\text { more than one active ingredient }\end{array}$ & [179] \\
\hline $\begin{array}{l}\text { Hunteria umbellata K. Schum. } \\
\text { (Apocynaceae, Gentianales) }\end{array}$ & $\begin{array}{l}\text { Fruit pulp, aqueous } \\
\text { extract }\end{array}$ & -1 & $\begin{array}{l}\text { Significant, dose-dependant effect on rat uterus con- } \\
\text { tractility; effect was blocked by atropine; potentiated } \\
\text { the response of oxytocin; active principle: muscarinic } \\
\text { cholinergic receptors }\end{array}$ & [149] \\
\hline $\begin{array}{l}\text { Iboza riparia (Hochst.) N. E. Br. } \\
\text { (Lamiaceae, Lamiales) }\end{array}$ & $\begin{array}{l}\text { Whole plants, water/ } \\
\text { methanol extract }\end{array}$ & -1 & Weak activity on uterus stimulation (guinea pig) ${ }^{4}$ & $\begin{array}{l}{[153,} \\
167]\end{array}$ \\
\hline $\begin{array}{l}\text { Leonurus artemisia (Lour.) S. Y. } \\
\text { Hu (Lamiaceae, Lamiales) }\end{array}$ & $\begin{array}{l}\text { Leaf, acidic methanol } \\
\text { extract }\end{array}$ & Leonurine (alkaloid) & $\begin{array}{l}\text { Stimulation of contractions in uterine smooth muscle; } \\
\text { stimulating effect may attribute to the restoration of } \\
\text { uterus to its normal size after birth }\end{array}$ & $\begin{array}{l}{[180,} \\
181]\end{array}$ \\
\hline $\begin{array}{l}\text { Luffa cylindrica (L.) M. Roem }{ }^{5} \\
\text { (Cucurbitaceae, Cucurbitales) }\end{array}$ & Leaf, aqueous extract & -6 & $\begin{array}{l}\text { Causes strong (oxytotic) uterine contractions, immedi- } \\
\text { ate and stable > } 30 \mathrm{~min} \text {; speed-up labour during child- } \\
\text { birth; rupturing of uterine membranes }\end{array}$ & [150] \\
\hline $\begin{array}{l}\text { Momordica foetida Schum. \& } \\
\text { Thonn. (Cucurbitaceae, Cucur- } \\
\text { bitales) }\end{array}$ & $\begin{array}{l}\text { Dry seeds, aqueous } \\
\text { extract }\end{array}$ & -1 & $\begin{array}{l}\text { Potent uterus contractile properties (rats), direct or } \\
\text { indirect intervention of } \mathrm{Ca}^{2+} \text {-ions or } \mathrm{Ca}^{2+} \text {-channels }\end{array}$ & [151] \\
\hline $\begin{array}{l}\text { Monechma ciliatum (Jacq.) } \\
\text { Milne-Redh. (Acanthaceae, } \\
\text { Lamiales) }\end{array}$ & $\begin{array}{l}\text { Leaf, hot methanol } \\
\text { extract }\end{array}$ & Amino acid/peptide 7 & Potent oxytocin-like activity on uterine smooth muscles & [147] \\
\hline $\begin{array}{l}\text { Montanoa tomentosa Cerv. } \\
\text { (Asteraceae, Asterales) }^{8}\end{array}$ & $\begin{array}{l}\text { Leaf, boiled aqueous } \\
\text { extracts; hexane frac- } \\
\text { tions }\end{array}$ & $\begin{array}{l}\text { Kaurenoic acid, grandi- } \\
\text { floric acid, kauradienoic } \\
\text { acid (kauranes) }\end{array}$ & $\begin{array}{l}\text { Contrary reports in the literature: Inhibition of sponta- } \\
\text { neous uterus contractions elicited by oxytocin, seroto- } \\
\text { nin or acetylcholine (assayed in rat); uterotonic activity, } \\
\text { i.e., increased tonus and frequency of contraction } \\
\text { (guinea pig, dog, cat, rabbit) }\end{array}$ & $\begin{array}{l}{[108-} \\
110]\end{array}$ \\
\hline $\begin{array}{l}\text { Musanga cecropioides R. Brown } \\
\text { (Urticaceae, Rosales) }\end{array}$ & $\begin{array}{l}\text { Stem bark, aqueous } \\
\text { extract }\end{array}$ & -1 & $\begin{array}{l}\text { Dose-dependent increase in the force of uterine con- } \\
\text { tractions; potentiating uterus contractions induced by } \\
\text { agonists; possibly by stimulation of muscarinic recep- } \\
\text { tors of the uterus }\end{array}$ & [182] \\
\hline $\begin{array}{l}\text { Newbouldia laevis (P. Beauv.) } \\
\text { Seem. ex Bureau (Bignonia- } \\
\text { ceae, Lamiales) }\end{array}$ & $\begin{array}{l}\text { Leaf, aqueous and } \\
\text { ethanolic extracts }\end{array}$ & -1 & $\begin{array}{l}\text { Increased frequency of spontaneous uterine contrac- } \\
\text { tions without affecting the amplitude; directly stimu- } \\
\text { lates uterine contractility, possibly by influencing the } \\
\text { open state of voltage dependent } \mathrm{Ca}^{2+} \text {-channels }\end{array}$ & [183] \\
\hline $\begin{array}{l}\text { Oldenlandia affinis (R\&S) DC } \\
\text { (Rubiaceae, Gentianales) }^{9}\end{array}$ & $\begin{array}{l}\text { Whole plant, aqueous ex- } \\
\text { tract (boiled preparation) }\end{array}$ & $\begin{array}{l}\text { Kalata B1, B2 and B7; circu- } \\
\text { lar polypeptides (cyclotides) }\end{array}$ & $\begin{array}{l}\text { Isotonic uterine contractions that do not get blocked by } \\
\text { serotonin-receptor antagonist; toxic in higher doses }\end{array}$ & $\begin{array}{l}{[115,} \\
121]\end{array}$ \\
\hline $\begin{array}{l}\text { Paris polyphylla Sm. var. yunna- } \\
\text { nensis (Franch.) Hand.-Mazz. } \\
\text { (Melanthiaceae, Liliales) }\end{array}$ & $\begin{array}{l}\text { Rhizome, hot ethanol } \\
\text { extract; bioassay-guided } \\
\text { fractionation }\end{array}$ & $\begin{array}{l}\text { Steroidal saponins, } \\
\text { spirostanol glycosides }\end{array}$ & $\begin{array}{l}\text { Dose-dependant induction of phasic myometrial con- } \\
\text { tractions (rat); phospholipase } \mathrm{C} \text { activation and }\left[\mathrm{Ca}^{2+}\right]_{\mathrm{i}} \\
\text { increase }\end{array}$ & [112] \\
\hline $\begin{array}{l}\text { Parquetina nigrescens (Afz.) } \\
\text { Bullock (Apocynaceae, Gentia- } \\
\text { nales) }\end{array}$ & $\begin{array}{l}\text { Leaf, hydro-methanolic } \\
\text { extract }\end{array}$ & -1 & $\begin{array}{l}\text { Increasing amplitude of spontaneous contractions and } \\
\text { slight elevation of muscular tonus (rat); calcium-depen- } \\
\text { dent }\end{array}$ & [184] \\
\hline $\begin{array}{l}\text { Petiveria alliacea L. (Phytolacca- } \\
\text { ceae, Caryophyllales) }\end{array}$ & $\begin{array}{l}\text { Seeds, methanolic } \\
\text { extract }\end{array}$ & -1 & $\begin{array}{l}\text { Causes contractions of uterus; increased frequency and } \\
\text { force of contraction on the contractile response to oxy- } \\
\text { tocin; could influence prostaglandin }\left(E_{2}, F_{2 \alpha}\right) \text { synthesis }\end{array}$ & [185] \\
\hline $\begin{array}{l}\text { Piper guineense L. (Piperaceae, } \\
\text { Piperales) }\end{array}$ & $\begin{array}{l}\text { Leaf and seeds, aqueous } \\
\text { extract (boiled prepara- } \\
\text { tion) }\end{array}$ & $\begin{array}{l}\text { Alkaloids, glycosides, flavo- } \\
\text { noids, phenols, phelobati- } \\
\text { nis, tannins, saponins, an- } \\
\text { tranoids, anthraquinone }\end{array}$ & $\begin{array}{l}\text { Enhances spontaneous uterine muscle contractions and } \\
\text { short-term treatment enhanced maximum contractile } \\
\text { response induced by oxytocin }\end{array}$ & [186] \\
\hline $\begin{array}{l}\text { Prorocentrum lima (Ehrenberg) } \\
\text { Stein (Dinophyta, Prorocentra- } \\
\text { ceae, Prorocentrales) }\end{array}$ & $\begin{array}{l}\text { Pure substance, isolated } \\
\text { from marine dinoflagel- } \\
\text { late }\end{array}$ & Okadaic acid & $\begin{array}{l}\text { Uterotonic contraction (rat), not mediated through ac- } \\
\text { tivation of membrane receptors or neurotransmitter re- } \\
\text { lease; no } \mathrm{Ca}^{2+} \text {-entry through dihydropyridine-sensitive } \\
\mathrm{Ca}^{2+} \text {-channels }\end{array}$ & [187] \\
\hline $\begin{array}{l}\text { Punica granatum L. (Punica- } \\
\text { ceae, Myrtales) }\end{array}$ & $\begin{array}{l}\text { "Pomegranate" seed, } \\
\text { methanol extract }\end{array}$ & $\beta$-sitosterol & $\begin{array}{l}\text { Potent stimulator of phasic activity in rat uterus; due } \\
\text { to non-oestrogenic effects of } \beta \text {-sitosterol as inhibitor } \\
\left.\text { of } \mathrm{K}^{+} \text {-channels and SERCA; [Ca } \mathrm{Ca}^{2+}\right]_{i} \text { increase via L-type } \\
\mathrm{Ca}^{2+} \text {-channels and myosin light chain kinase activation }\end{array}$ & [113] \\
\hline $\begin{array}{l}\text { Rhoicissus tridentata (L.f.) Wild } \\
\text { \& R. B. Drumm. (Vitaceae, } \\
\text { Vitales) }\end{array}$ & $\begin{array}{l}\text { Roots and lignotubers, } \\
\text { aqueous extract (boiled } \\
\text { preparation) }\end{array}$ & -1 & $\begin{array}{l}\text { Stimulates contractions of isolated rat uterus directly; } \\
\text { contractile response is mediated predominantly by the } \\
\text { muscarinic receptor system and the production of cy- } \\
\text { clooxygenase metabolites }\end{array}$ & [188] \\
\hline
\end{tabular}


Table 1 Uterotonic plants and their active compounds. (continued)

\begin{tabular}{|c|c|c|c|c|}
\hline $\begin{array}{l}\text { Plant (scientific name; } \\
\text { family, order) }\end{array}$ & Part of plant, extract & Active compound(s) & Uterotonic principle (mode-of-action) & Refs. \\
\hline $\begin{array}{l}\text { Schisandra chinensis (Turcz.) } \\
\text { Baill. (Schisandraceae, Austro- } \\
\text { baileyales) }\end{array}$ & $\begin{array}{l}\text { Tinctures of seeds and } \\
\text { berries (ethanol) }\end{array}$ & -1 & $\begin{array}{l}\text { Uterus myotonic activity; stimulated the contraction of } \\
\text { the uterus isolated from cats or rabbits }\end{array}$ & [189] \\
\hline $\begin{array}{l}\text { Solanum americanum L. (Sola- } \\
\text { naceae, Solanales) }\end{array}$ & $\begin{array}{l}\text { Green fruit, aqueous } \\
\text { extract }\end{array}$ & $\begin{array}{l}\text { Saponins, glycol-alka- } \\
\text { loids }\end{array}$ & Stimulation of uterine contractions & [190] \\
\hline $\begin{array}{l}\text { Spondias mombin Lindl. (Ana- } \\
\text { cardiaceae, Sapindales) }\end{array}$ & Leaf, methanol extract & $\begin{array}{l}\text { Tannins, saponins, flavo- } \\
\text { noids, proteins, glycosides, } \\
\text { resins, triterpenes, steroids }\end{array}$ & $\begin{array}{l}\text { Oxytotic activity, may derive from } \mathrm{Ca}^{2+} \text {-ion mobilisation } \\
\text { from the cytosol and direct musculotropic effects }\end{array}$ & [148] \\
\hline $\begin{array}{l}\text { Trichosanthes kirilowii Maxim. } \\
\text { (Cucurbitaceae, Cucurbitales) }\end{array}$ & Root, extract & -1 & $\begin{array}{l}\text { Strengthened spontaneous contractions and enhanced } \\
\text { response of uterus muscle to prostaglandin } F_{2 \alpha} \text { and } \\
\text { oxytocin }\end{array}$ & [152] \\
\hline $\begin{array}{l}\text { Vitex doniana Sweet (Lamia- } \\
\text { ceae, Lamiales) }\end{array}$ & $\begin{array}{l}\text { Bark, aqueous extract } \\
\text { (boiled preparation) }\end{array}$ & -1 & $\begin{array}{l}\text { Induced graded uterine contractions and potentiated } \\
\text { the effects of prostaglandins, ergometrine and oxyto- } \\
\text { cin; may act on voltage operated ion-channels and ute- } \\
\text { rotonic receptors }\end{array}$ & [191] \\
\hline
\end{tabular}

${ }^{1}$ Active compounds have not yet been identified. ${ }^{2}$ These compounds are also found in Montanoa tomentosa. ${ }^{3}$ Formerly known as Excoecaria bicolor Zoll. Ex. Hassk. ${ }^{4}$ Pharmacological evidence not clear, since the extract also showed relaxing activity on skeletal and ileum smooth muscle. ${ }^{5}$ Other species of the genus Luffa, e.g., L. echinata also show what has been reported to be uterotonic activity [192]. ${ }^{6}$ L. cyclindrica contains ribosome-inactivating proteins, that are thought to be responsible for its abortifacient activity in mice [193]. ${ }^{7}$ Active compound is possibly a small peptide with the sequence YLS. ${ }^{8}$ Other Montanoa spp. (i.e., M. frutescens, M. hibiscifolia) report uterotonic and spasmolytic activities. ${ }^{9}$ Other species from Violaceae and Rubiaceae do contain cyclotides, potentially with uterotonic activity.

therefore appears to be as plant defence molecules based on their insecticidal properties $[133,134]$; however, additional roles may yet be identified.

Recent studies on the evolution, distribution and abundance of cyclotides in plants has led to the conclusion that there are at least 9000 novel cyclotides to be discovered in the violet family (Violaceae) [135] and an even greater number (up to 50000) in the coffee family (Rubiaceae) [136]. The discovery of cyclotides and cyclotide-like proteins in other monocotyledon [137] and dicotyledon plant families suggests that cyclotides are much more numerous than originally anticipated. The family of cyclotides impresses not only by their sheer number, but also by their diversity. Typically one species can express 15-60 different, unique cyclotides $[136,138]$ and a recent report suggests this number may be increased by varying growth conditions [139]. Their diversity is a result of the conserved cysteine framework and the backbone chains (loops) between those cysteines ( Fig. 4), which are tolerant to various amino acid combinations. The plasticity and stability of the cyclotide framework and its tolerance to substitution [140] have been recently used as a tool for the development of novel pharmaceutical agents [141,142] and these examples underpin the application of cyclotides as combinatorial peptide scaffolds in pharmaceutical drug design.

It has been suggested that cyclotides have evolved independently in various plant families [136]. It may be too early to provide a reliable, evidence-based evolutionary mechanism of cyclotides in flowering plants since "only" 500 different species $(\stackrel{\underline{ }}{\wedge} 0.2 \%$ of total) from a total of $>250000$ existing flowering plant species have been analysed to date [143]. Hence, it has to be clear that many more plant species need to be tested before it will be possible to make reliable conclusions on the origin and evolution of cyclotides within the plant kingdom. However, it is likely that cyclotides will ultimately comprise one of the largest protein families within the plant kingdom [136] and hence constitute an immense library of natural peptides, which may also be tested in the future for uterotonic activities. A starting point for future cyclotide discovery efforts would be plant families and orders that are in close phylogenetic proximity to the already positively identified ones, e.g., Celestrales, Oxalidales, Fabales, Rosales, Lamiales and Solanales ( $\odot$ Fig. 4), and considering the number of species in each of these orders, there is great potential for future cyclotide discoveries.

\section{Conclusion and Outlook \\ $\nabla$}

The quest for novel uterotonic, cyclotide-producing plants

Cyclotides are interesting targets for pharmaceutical and agrochemical applications due to their unique structural framework, range of bioactivities and sequence diversity [144-146] and based on their predicted number, which makes them one of the largest protein families within the plant kingdom, they constitute an immense library of natural peptides, which is accessible for drug discovery efforts [124].

Only recently have we started to comprehend the diversity and distribution of cyclotides and it seems likely that many more circular plant peptides await discovery and analysis. In the search for novel cyclotide-containing species one can apply the "taxonomy-guided" discovery approach (as discussed above), i.e., the analysis of novel cyclotide-related plants on a species and family level, and the "activity-guided" discovery approach by processing ethnobotanical and ethnopharmacological information followed by plant analysis. A closer look at other uterotonic plant species ( Table 1) reveals starting points for further cyclotide discovery efforts. For example, the oxytocic activity from Monechma ciliatum [147] and Spondias mombin [148] is thought to be derived (at least in part) from amino acids and/or peptides, however, the exact nature of the active components is not yet known. Other uterotonic plants, of which the active constituents are not yet elucidated, belong to the same families of already known cyclotide- or cyclotide-like containing plant families, namely Asclepias fructicosa [76], Hunteria umbellata (both Apocynaceae) [149], Luffa cylindrica [150], Momordica foetida [151] and Trichosanthes kirilowii [152] (all Cucurbitaceae). Furthermore, there are plants that have been traditionally used during pregnancy, childbirth 


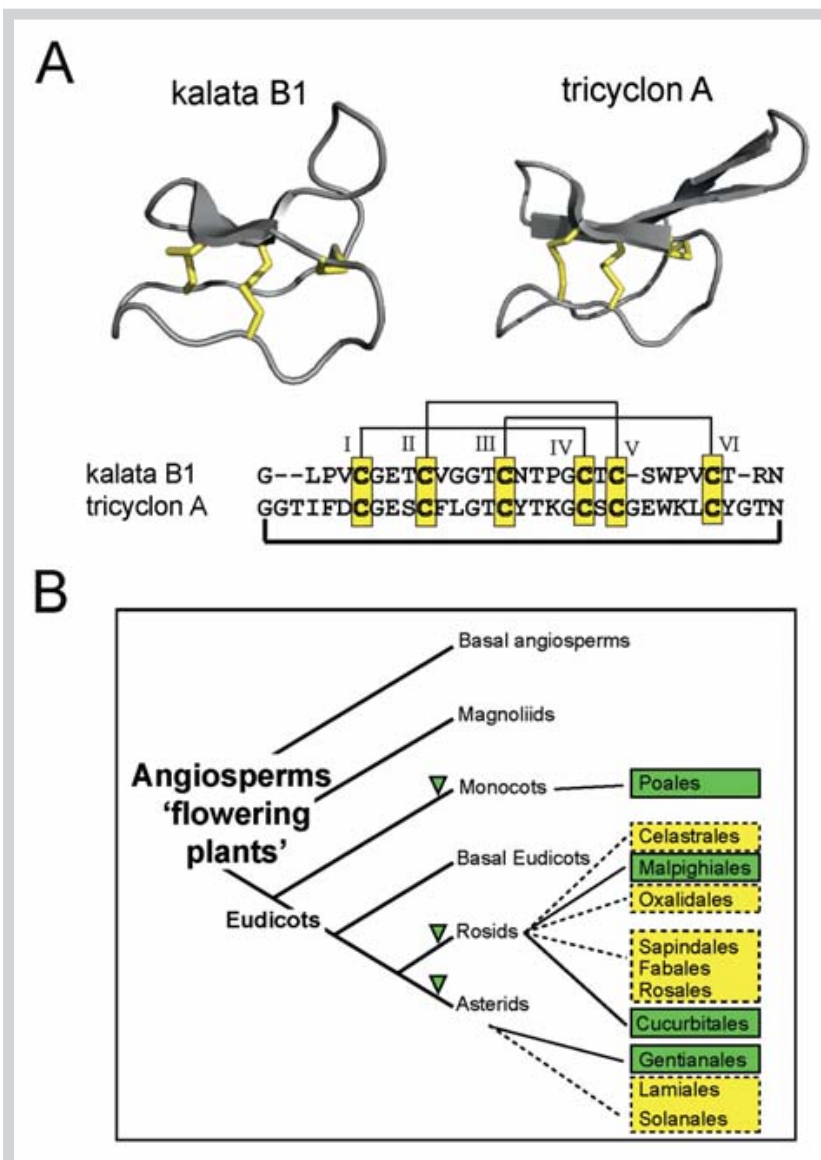

Fig. 4 Structure and distribution of plant cyclotides. A Cyclotides, such as kalata B1 and tricyclon A comprise the typical structural cyclic cystine knot motif, characterised by three disulfide bonds (shown in yellow) in a knotted arrangement (two disulfide bonds and the adjacent backbone segments form a ring that is threaded by the third disulfide bond). The characteristic anti-parallel $\beta$-sheets are shown in grey cartoon. The backbone amino acids (sequence alignment shown below the structure cartoons) are separated by the Cys residues (numbered with Roman numerals) into six loops and the $\mathrm{N}$ - and C-terminal amino acids are linked to form the circle. B Presently known cyclotide- or cyclotide-like containing orders within the flowering plants are shown in green. The angiosperm phylogeny tree has been adapted and modified from the Angiosperm Phylogeny Group [194]. The family Rubiaceae belongs to the order of Gentianales, Violaceae to the order of Malphigiales, Cucurbitaceae to the order of Cucurbitales and Poaceae, a monocotyledon plant, belongs to the order of Poales. Other plant orders that have either ethnopharmacological similarity (i.e., uterotonic activity) or a close taxonomic relationship to the respective positivelytested cyclotide orders (e.g., Celestrales, Oxalidales, Sapindales, Fabales, Rosales, Lamiales and Solanales) are marked in yellow and could be starting point for further cyclotide discovery.

and gynaecological health-care, but have not yet been pharmacologically tested for uterotonic activity, such as Cephaelis tomentosa (Aubl.) Vahl. [97], Pentanisia prunelloides (Eckl.+Zeyh.) Walp. [98], Rondeletia stachyoidea Donn. Smith [97], Spermacoce princeae (K. Schum.) Verdc. [153], Vangueria apiculata K. Schum. [153] (all Rubiaceae), Acokanthera abyssinica K. Schum. [96], Calotropis procera (Ait.) Dryand. [96] and Rauvolfia caffra Sond. [98] (all Apocynaceae).

Both the taxonomy-guided and the activity-guided discovery approaches may lead to finding novel cyclotide-producing plant species, which will not only help to understand their diversity and evolution, but also provide novel molecules for biological testing and potentially new entities for drug development of uterotonic as well as tocolytic agents.

\section{Importance of uterine active agents for clinical use}

During pregnancy the uterus undergoes dramatic changes in its contractile activity, going from a state of quiescence to one of maximal contractile activity at labour. The initiation of labour is a complex physiological process that requires the expression and secretion of many maternal and foetal factors that exert their effect on the myometrium, the uterine smooth muscle responsible for expelling the foetus from the uterus in strong synchronous contractions. Abnormalities of this process have major clinical implications, including preterm labour, the single largest cause of maternal and perinatal mortality in developed countries and a major contributor to childhood developmental problems $[154,155]$. An estimated $28 \%$ of the 4 million annual neonatal deaths are due to preterm birth and approximately 12.9 million babies are born prematurely every year, which estimates to a global prevalence of preterm birth of $9.6 \%[156,157]$. This results in huge costs to healthcare systems internationally. Figures from 2005 from the USA indicate that the annual societal economic cost (medical, educational, and lost productivity) associated with preterm birth from birth through early childhood was at least US\$26.2 billion [158].

Currently used intervention therapies to suppress uterine contractions and delay labour, have harmful side effects for mother and baby. There is both a clinical need and a commercial opportunity for the identification of novel therapeutic agents for preterm labour. Current, so-called tocolytic therapies to inhibit preterm labour remain targeted at modulating uterine contractions. The only FDA approved treatment for preterm labour is ritodrine, a $\beta_{2}$-adrenergic receptor agonist. However, it was withdrawn in 1999, due to side effects. A more widely used treatment for preterm labour, terbutaline, is not approved by the FDA for preterm labour. Other tocolytics include magnesium sulphate and nifepidine. The usefulness of $\beta_{2}$-adrenergic agonists is limited by the side effects they produce, including cardiovascular side effects, such as heart palpitations (via stimulation of $\beta_{1}$-adrenergic receptors). The side effects of PG synthesis inhibitors are well known and include ulcers, asthma and cardiovascular problems. Atosiban, an OT antagonist is available in Europe, but was denied regulatory approval in the USA. Thus, there is a need for treatments that are effective in reducing the premature birth rate and/or providing for longer gestation, with better safety and tolerability profiles. The ideal tocolytic agent would be highly specific for uterine smooth muscle and would have minimal side effects for both mother and neonate.

In contrast, induction of labour may be necessary in certain conditions and is advocated in cases of post-term pregnancy, lack of progress, oligohydramnios, suspected intrauterine growth restriction, maternal cardiac disease, pre-eclampsia/eclampsia, pre-labour rupture of membranes at term and foetal macrosomia [159]. Uterotonic or oxytocic drugs are used to induce or augment labour and in the prevention or treatment of post-partum bleeding [160]. OT is used for labour induction and associated complications during the third stage of labour include post-partum haemorrhage, retained placenta and uterine inversion [161]. Furthermore, PGs are used to induce labour and to prevent or treat post-partum haemorrhage [162], while synthetic ergot alkaloids cause strong titanic contraction of the uterus.

In summary, there is a great need for potent, selective and nontoxic therapeutic agents (agonists and antagonists) for recep- 
tors/signalling pathways that regulate uterine muscle action. Traditionally used herbal medicines and their active ingredients, such as cyclotides found in flowering plants, are ideal starting points for biological target-oriented drug discovery efforts. The search for novel cyclotide-producing plants and their pharmacological characterisation may eventually lead to the development of novel uterotonic or tocolytic drugs.

\section{Acknowledgements}

The authors would like to thank C. Dobeš and B. Šarić-Kundalić for useful comments. Work on bioactive peptides and GPCR signalling in the laboratory of CWG is supported by the Austrian Science Fund (FWF; M1086 and P22889) and the European Union (Marie Curie, FP7, IRG no. 23 097). Work on reproductive biology by MO'B is supported by the Health Research Board of Ireland, the Higher Education Authority of Ireland's Programme for Research in Third Level Institutions and the National University of Ireland, Galway, Ireland.

\section{References}

1 Symonds EM, Symonds IM. Essential obstetrics and gynaecology. 3rd edition. Edinburgh: Churchill Livingstone; 1998: 26-31

2 Alberts B, Bray D, Lewis J, Raff M, Roberts K, Watson JD. Molecular biology of the cell. 2nd edition. New York, London: Garland Publishing; 1989: 984

3 Csapo AI. Smooth muscle as a contractile unit. Physiol Rev Suppl 1962; 5: 7-33

4 Young $R C$. Myocytes, myometrium, and uterine contractions. Ann N Y Acad Sci 2007; 1101: 72-84

5 Somlyo AP, Somlyo AV. Smooth muscle structure and function. In: Fozzard HA, ed. The heart and cardiovascular system. New York: Raven Press; 1991: 1295-1324

6 Olson NJ, Pearson RB, Needleman DS, Hurwitz MY, Kemp BE, Means AR. Regulatory and structural motifs of chicken gizzard myosin light chain kinase. Proc Natl Acad Sci USA 1990; 87: 2284-2288

7 Stull JT, Tansey MG, Word RA, Kubota Y, Kamm KE. Myosin light chain kinase phosphorylation: regulation of the $\mathrm{Ca}^{2+}$ sensitivity of contractile elements. Adv Exp Med Biol 1991; 304: 129-138

8 Sakurada K, Seto M, Sasaki Y. Dynamics of myosin light chain phosphorylation at Ser19 and Thr18/Ser19 in smooth muscle cells in culture. Am J Physiol 1998; 274: C1563-C1572

9 Sanborn BM. Ion channels and the control of myometrial electrical activity. Semin Perinatol 1995; 19: 31-40

10 Lopez Bernal A. Overview. Preterm labour: mechanisms and management. BMC Pregnancy Childbirth 2007; 7 (Suppl. 1): S2

11 Sanborn BM, Yue C, Wang W, Dodge KL. G protein signalling pathways in myometrium: affecting the balance between contraction and relaxation. Rev Reprod 1998; 3: 196-205

12 Wickman KD, Clapham DE. G-protein regulation of ion channels. Curr Opin Neurobiol 1995; 5: 278-285

13 Ivell $R$, Richter $D$. Structure and comparison of the oxytocin and vasopressin genes from rat. Proc Natl Acad Sci USA 1984; 81: 2006-2010

14 Owen J, Hauth JC. Oxytocin for the induction or augmentation of labor. Clin Obstet Gynecol 1992; 35: 464-475

15 Chard T. Fetal and maternal oxytocin in human parturition. Am J Perinatol 1989; 6: 145-152

16 Fuchs AR, Husslein P, Kofler E, Grunberger W, Rasmussen A, Rehnstrom J. Effect of cervical application of prostaglandin (PG) E2 on plasma 13, 14-dihydro-15-keto-PGF2 alpha and oxytocin in pregnant women at term. Br J Obstet Gynaecol 1983; 90: 612-617

17 Clarke G, Lincoln DW. Proceedings: Evidence for a dopaminergic component in the milk-ejection reflex of the rat. J Endocrinol 1975; 67: 33P-34P

18 Mitchell BF, Schmid B. Oxytocin and its receptor in the process of parturition. J Soc Gynecol Investig 2001; 8: 122-133

19 Ku CY, Qian A, Wen Y, Anwer K, Sanborn BM. Oxytocin stimulates myometrial guanosine triphosphatase and phospholipase-C activities via coupling to $\mathrm{G}$ alpha q/11. Endocrinology 1995; 136: 1509-1515
20 Anwer K, Hovington JA, Sanborn BM. Antagonism of contractants and relaxants at the level of intracellular calcium and phosphoinositide turnover in the rat uterus. Endocrinology 1989; 124: 2995-3002

21 Anwer K, Sanborn BM. Changes in intracellular free calcium in isolated myometrial cells: role of extracellular and intracellular calcium and possible involvement of guanine nucleotide-sensitive proteins. Endocrinology 1989; 124: 17-23

22 Young $R C$, Zhang $P$. The mechanism of propagation of intracellular calcium waves in cultured human uterine myocytes. Am J Obstet Gynecol 2001; 184: 1228-1234

23 Batra S. Effect of oxytocin on calcium influx and efflux in the rat myometrium. Eur J Pharmacol 1986; 120: 57-61

24 Monga M, Campbell DF, Sanborn BM. Oxytocin-stimulated capacitative calcium entry in human myometrial cells. Am J Obstet Gynecol 1999; 181: 424-429

25 Soloff MS, Jeng YJ, Copland JA, Strakova Z, Hoare S. Signal pathways mediating oxytocin stimulation of prostaglandin synthesis in select target cells. Exp Physiol 2000; 85: 51S-58S

26 Mitchell MD, Romero RJ, Edwin SS, Trautman MS. Prostaglandins and parturition. Reprod Fertil Dev 1995; 7: 623-632

27 Kelly AJ, Malik S, Smith L, Kavanagh J, Thomas J. Vaginal prostaglandin (PGE2 and PGF2a) for induction of labour at term. Cochrane Database Syst Rev 2009; 4: CD003101

28 Brodt-Eppley J, Myatt L. Prostaglandin receptors in lower segment myometrium during gestation and labor. Obstet Gynecol 1999; 93: 89-93

29 Lopez Bernal A. Mechanisms of labour-biochemical aspects. BJOG 2003; 110 (Suppl. 20): 39-45

30 Carsten ME, Miller JD. Effects of prostaglandins and oxytocin on calcium release from a uterine microsomal fraction. J Biol Chem 1977; 252: $1576-1581$

31 Ashby B. Co-expression of prostaglandin receptors with opposite effects: a model for homeostatic control of autocrine and paracrine signaling. Biochem Pharmacol 1998; 55: 239-246

32 Molnar M, Hertelendy F. PGF2 alpha and PGE2 binding to rat myometrium during gestation, parturition, and postpartum. Am J Physiol 1990; 258: E740-E747

33 Phaneuf S, Europe-Finner GN, Varney M, MacKenzie IZ, Watson SP, Lopez Bernal A. Oxytocin-stimulated phosphoinositide hydrolysis in human myometrial cells: involvement of pertussis toxin-sensitive and -insensitive G-proteins. J Endocrinol 1993; 136: 497-509

34 Asboth G, Phaneuf S, Europe-Finner GN, Toth M, Bernal AL. Prostaglandin E2 activates phospholipase $C$ and elevates intracellular calcium in cultured myometrial cells: involvement of EP1 and EP3 receptor subtypes. Endocrinology 1996; 137: 2572-2579

35 Matsumoto T, Sagawa N, Yoshida M, Mori T, Tanaka I, Mukoyama M, Kotani $\mathrm{M}$, Nakao K. The prostaglandin E2 and F2 alpha receptor genes are expressed in human myometrium and are down-regulated during pregnancy. Biochem Biophys Res Commun 1997; 238: 838-841

36 Garfield RE, Kannan MS, Daniel EE. Gap junction formation in myometrium: control by estrogens, progesterone, and prostaglandins. Am J Physiol 1980; 238: C81-C89

37 Vane JR, Williams KI. The contribution of prostaglandin production to contractions of the isolated uterus of the rat. $\mathrm{Br} J$ Pharmacol 1973; 48: 629-639

38 Poyser NL. Differential stimulation of prostaglandin and thromboxane synthesizing capacities in guinea-pig uterus and ovary. Prostaglandins Leukot Med 1983; 10: 163-177

39 Reis FM, Fadalti M, Florio P, Petraglia F. Putative role of placental corticotropin-releasing factor in the mechanisms of human parturition. J Soc Gynecol Investig 1999; 6: 109-119

40 Grammatopoulos DK, Hillhouse EW. Role of corticotropin-releasing hormone in onset of labour. Lancet 1999; 354: 1546-1549

41 Hillhouse EW, Grammatopoulos DK. Role of stress peptides during human pregnancy and labour. Reproduction 2002; 124: 323-329

42 Grammatopoulos DK, Hillhouse EW. Basal and interleukin-1 beta-stimulated prostaglandin production from cultured human myometrial cells: differential regulation by corticotropin-releasing hormone. J Clin Endocrinol Metab 1999; 84: 2204-2211

43 Grammatopoulos DK, Hillhouse EW. Activation of protein kinase C by oxytocin inhibits the biological activity of the human myometrial corticotropin-releasing hormone receptor at term. Endocrinology 1999; 140: $585-594$

44 Jones $S A$, Challis JR. Local stimulation of prostaglandin production by corticotropin-releasing hormone in human fetal membranes and placenta. Biochem Biophys Res Commun 1989; 159: 192-199 
45 Karalis K, Goodwin G, Majzoub JA. Cortisol blockade of progesterone: a possible molecular mechanism involved in the initiation of human labor. Nat Med 1996; 2: 556-560

46 Smith $R$. Parturition. N Engl J Med 2007; 356: 271-283

47 Kostrzewska A, Laudanski T, Batra S. Effect of ovarian steroids and diethylstilbestrol on the contractile responses of the human myometrium and intramyometrial arteries. Eur J Pharmacol 1993; 233: 127-134

48 Ruzycky AL, Kulick A. Estrogen increases the expression of uterine protein kinase $C$ isozymes in a tissue specific manner. Eur J Pharmacol 1996; 313: 257-263

49 Zeeman GG, Khan-Dawood FS, Dawood MY. Oxytocin and its receptor in pregnancy and parturition: current concepts and clinical implications. Obstet Gynecol 1997; 89: 873-883

50 Green S, Kumar V, Krust A, Walter P, Chambon P. Structural and functional domains of the estrogen receptor. Cold Spring Harb Symp Quant Biol 1986; 51 (Pt 2): 751-758

51 Kuiper GG, Enmark E, Pelto-Huikko M, Nilsson S, Gustafsson JA. Cloning of a novel receptor expressed in rat prostate and ovary. Proc Natl Acad Sci USA 1996; 93: 5925-5930

52 Csapo A. The mechanism of effect of the ovarian steroids. Recent Prog Horm Res 1956; 12: 405-431

53 Garfield RE, Ali M, Yallampalli C, Izumi H. Role of gap junctions and nitric oxide in control of myometrial contractility. Semin Perinatol 1995; 19: 41-51

54 Haluska GJ, Wells TR, Hirst JJ, Brenner RM, Sadowsky DW, Novy MJ. Progesterone receptor localization and isoforms in myometrium, decidua, and fetal membranes from rhesus macaques: evidence for functional progesterone withdrawal at parturition. J Soc Gynecol Investig 2002; 9: $125-136$

55 Mohan AR, Loudon JA, Bennett PR. Molecular and biochemical mechanisms of preterm labour. Semin Fetal Neonatal Med 2004; 9: 437-444

56 Yoon BH, Romero R, Jun JK, Maymon E, Gomez R, Mazor M, Park JS. An increase in fetal plasma cortisol but not dehydroepiandrosterone sulfate is followed by the onset of preterm labor in patients with preterm premature rupture of the membranes. Am J Obstet Gynecol 1998; 179: 1107-1114

57 Garbrecht MR, Klein JM, Schmidt TJ, Snyder JM. Glucocorticoid metabolism in the human fetal lung: implications for lung development and the pulmonary surfactant system. Biol Neonate 2006; 89: 109-119

58 Condon JC, Jeyasuria P, Faust JM, Mendelson CR. Surfactant protein secreted by the maturing mouse fetal lung acts as a hormone that signals the initiation of parturition. Proc Natl Acad Sci USA 2004; 101: 49784983

59 Osman I, Young A, Ledingham MA, Thomson AJ, Jordan F, Greer IA, Norman JE. Leukocyte density and pro-inflammatory cytokine expression in human fetal membranes, decidua, cervix and myometrium before and during labour at term. Mol Hum Reprod 2003; 9: 41-45

60 Thomson AJ, Telfer JF, Young A, Campbell S, Stewart CJ, Cameron IT, Greer $I A$, Norman JE. Leukocytes infiltrate the myometrium during human parturition: further evidence that labour is an inflammatory process. Hum Reprod 1999; 14: 229-236

61 Opsjln SL, Wathen NC, Tingulstad S, Wiedswang G, Sundan A, Waage A, Austgulen $R$. Tumor necrosis factor, interleukin-1, and interleukin-6 in normal human pregnancy. Am J Obstet Gynecol 1993; 169: 397-404

62 Romero R, Mazor M, Sepulveda W, Avila C, Copeland D, Williams J. Tumor necrosis factor in preterm and term labor. Am J Obstet Gynecol 1992; 166: $1576-1587$

63 Keelan JA, Marvin KW, Sato TA, Coleman M, McCowan LM, Mitchell MD. Cytokine abundance in placental tissues: evidence of inflammatory activation in gestational membranes with term and preterm parturition. Am J Obstet Gynecol 1999; 181: 1530-1536

64 Steinborn A, Gunes H, Roddiger S, Halberstadt E. Elevated placental cytokine release, a process associated with preterm labor in the absence of intrauterine infection. Obstet Gynecol 1996; 88: 534-539

65 Elliott CL, Allport VC, Loudon JA, Wu GD, Bennett PR. Nuclear factor-kappa $B$ is essential for up-regulation of interleukin-8 expression in human amnion and cervical epithelial cells. Mol Hum Reprod 2001; 7: $787-790$

66 Olson DM. The role of prostaglandins in the initiation of parturition. Best Pract Res Clin Obstet Gynaecol 2003; 17: 717-730

67 Chow L, Lye SJ. Expression of the gap junction protein connexin-43 is increased in the human myometrium toward term and with the onset of labor. Am J Obstet Gynecol 1994; 170: 788-795
68 Fuchs AR, Fuchs F, Husslein P, Soloff MS. Oxytocin receptors in the human uterus during pregnancy and parturition. Am J Obstet Gynecol 1984; 150: 734-741

69 Soloff MS, Cook Jr DL, Jeng YJ, Anderson GD. In situ analysis of interleukin-1-induced transcription of cox-2 and il-8 in cultured human myometrial cells. Endocrinology 2004; 145: 1248-1254

70 Smith R. Mechanisms of disease - parturition. N Engl J Med 2007; 356: 271-283

71 Fry $\mathrm{CH}$. Experimental models to study the physiology, pathophysiology, and pharmacology of the lower urinary tract. J Pharmacol Toxicol Methods 2004; 49: 201-210

72 Sakmann $B$, Neher $E$. Patch clamp techniques for studying ionic channels in excitable membranes. Annu Rev Physiol 1984; 46: 455-472

73 Herrero M, Mendiola JA, Cifuentes A, Ibanez E. Supercritical fluid extraction: Recent advances and applications. J Chromatogr A 2010; 1217: 2495-2511

74 Reverchon E. Supercritical fluid extraction and fractionation of essential oils and related products. J Supercrit Fluids 1997; 10: 1-37

75 Sewram V, Raynor MW, Mulholland DA, Raidoo DM. Supercritical fluid extraction and analysis of compounds from Clivia miniata for uterotonic activity. Planta Med 2001; 67: 451-455

76 Sewram V, Raynor MW, Raidoo DM, Mulholland DA. Coupling SFE to uterotonic bioassay: an on-line approach to analysing medicinal plants. J Pharm Biomed Anal 1998; 18: 305-318

77 Veale DJH, Oliver DW, Arangies NS, Furman KI. Preliminary isolated organ studies using an aqueous extract of Clivia miniata leaves. J Ethnopharmacol 1989; 27: 341-346

78 Bell E, Ivarsson B, Merrill C. Produaction of a tissue-like strcuture by contraction of collagen lattices by human-fibroblasts of different proliferative potential in vitro. Proc Natl Acad Sci USA 1979; 76: 1274 1278

79 Dallot E, Pouchelet M, Gouhier N, Cabrol D, Ferre F, Breuiller-Fouche M. Contraction of cultured human uterine smooth muscle cells after stimulation with endothelin-1. Biol Reprod 2003; 68: 937-942

80 Devost $\mathrm{D}$, Zingg $\mathrm{HH}$. Novel in vitro system for functional assessment of oxytocin action. Am J Physiol Endocrinol Metab 2007; 292: E1-E6

81 Ivanov V, Roomi MW, Kalinovsky T, Niedzwiecki A, Rath $M$. Natural nutrient mixture effectively reduces collagen matrix contraction driven by human uterine smooth muscle cells. J Obstet Gynaecol Res 2006; 32: $23-31$

82 Fitzgibbon J, Morrison JJ, Smith TJ, O'Brien M. Evaluation of the effect of known mediators on human uterine smooth muscle cell contractility. Reprod Sci 2008; 15: 116A

83 Fitzgibbon J, Morrison JJ, Smith TJ, O'Brien M. Modulation of human uterine smooth muscle cell collagen contractility by thrombin, Y27632, TNF alpha and indomethacin. Reprod Biol Endocrinol 2009; 7: 2

84 O'Brien M, Fitzgibbon J, Morrison JJ, Smith TJ. Thrombin stimulation of human uterine smooth muscle cell collagen contractility. Reprod Sci 2009; 16: 296A

85 Martinez GJ. Traditional practices, beliefs and uses of medicinal plants in relation to maternal-baby health of Criollo woman in central Argentina. Midwifery 2008; 24: 490-502

86 Wilkowski $R$. Chinese medicine for pregnancy and childbirth. Midwifery Today Int Midwife 2001: 39-41

87 Zhu X, Proctor M, Bensoussan A, Wu E, Smith CA. Chinese herbal medicine for primary dysmenorrhoea. Cochrane Database Syst Rev 2008; 2 : CD005288

88 Ososki AL, Lohr P, Reiff M, Balick MJ, Kronenberg F, Fugh-Berman A, O'Connor $B$. Ethnobotanical literature survey of medicinal plants in the Dominican Republic used for women's health conditions. J Ethnopharmacol 2002; 79: 285-298

89 Ticktin T, Dalle SP. Medicinal plant use in the practice of midwifery in rural Honduras. J Ethnopharmacol 2005; 96: 233-248

90 Zumsteg IS, Weckerle CS. Bakera, a herbal steam bath for postnatal care in Minahasa (Indonesia): Documentation of the plants used and assessment of the method. J Ethnopharmacol 2007; 111: 641-650

91 de Boer H, Lamxay V. Plants used during pregnancy, childbirth and postpartum healthcare in Lao PDR: a comparative study of the Brou, Saek and Kry ethnic groups. J Ethnobiol Ethnomed 2009; 5: 25

92 Browner $\mathrm{CH}$. Plants used for reproductive health in Oaxaca, Mexico. Econ Bot 1985; 39: 482-504

93 Singh YN, Ikahihifo T, Panuve M, Slatter C. Folk medicine in Tonga - a study on the use of herbal medicines for obstetric and gynecological conditions and disorders. J Ethnopharmacol 1984; 12: 305-329 
94 Bourdy G, Walter A. Maternity and medicinal plants in Vanuatu. 1. The cycle of reproduction. J Ethnopharmacol 1992; 37: 179-196

95 Wang LL, Nankorn W, Fukui K. Food and medicinal plants used for childbirth among Yunanese Chinese in Northern Thailand. J Ethnobiol 2003; 23: 209-226

96 Desta B. Ethiopian traditional herbal drugs. 3. Anti-fertility activity of 70 medicinal plants. J Ethnopharmacol 1994; 44: 199-209

97 Michel J, Duarte RE, Bolton JL, Huang Y, Caceres A, Veliz M, Soejarto DD, Mahady GB. Medical potential of plants used by the Q'eqchi Maya of Livingston, Guatemala for the treatment of women's health complaints. J Ethnopharmacol 2007; 114: 92-101

98 Veale DJH, Furman KI, Oliver DW. South African traditional herbal medicines used during pregnancy and childbirth. J Ethnopharmacol 1992; 36: 185-191

99 Westfall RE. Herbal medicine in pregnancy and childbirth. Adv Ther 2001; 18: 47-55

100 Whitehouse B. Fragarine an inhibitor of uterine action (Preliminary communication). Br Med J 1941; 2 (4210): 370-371

101 Kelly AJ, Kavanagh J, Thomas J. Castor oil, bath and/or enema for cervical priming and induction of labour. Cochrane Database Syst Rev 2001; 2: CD003099

102 Nissim R. Natural healing in gynaecology: a manual for women (Pandora's Health). London: Thorsons Publishers; 1996: 220

103 Bayles BP. Herbal and other complementary medicine use by Texas midwives. J Midwifery Womens Health 2007; 52: 473-478

104 Born D, Barron ML. Herb use in pregnancy: what nurses should know. MCN Am J Matern Child Nurs 2005; 30: 201-208

105 Gerlach S, Saukel J, Kubelka W. Pflanzen in der österreichischen Volksmedizin. Die "VOLKSMED-DATENBANK". Sci Pharm 2006; 74 (Suppl. 1): 36

106 Šarić-Kundalić B. Traditional medicine of the Balkans with identification and examination of the collected material [dissertation]. Vienna: University of Vienna; 2010

107 Hijazi AM, Salhab AS. Effects of Artemisia monosperma ethanolic leaves extract on implantation, mid-term abortion and parturition of pregnant rats. J Ethnopharmacol 2010; 128: 446-451

108 Campos Bedolla P, Campos MG, Valencia Sanchez A, Ponce Monter H, Uribe C, Osuna L, Calderon J. Effect of kauranes from Montanoa spp on rat uterus. Phytother Res 1997; 11: 11-16

109 Lozoya X, Enriquez RG, Bejar E, Estrada AV, Giron H, Poncemonter $H$, Gallegos AJ. The zoapatle. 5. The effect of kauradienoic acid upon uterine contractility. Contraception 1983; 27: 267-279

110 Perusquia M, Sanchez E, Poncemonter H, Estrada AV, Pedron N, Valencia A, Guzman A, Gallegos AJ. The zoapatle. 11. Effects elicited by Montanoa tomentosa and Montanoa frutescens on rat uterine strips. Contraception 1985; 31: 543-551

111 Khan F, Peter XK, Mackenzie RM, Katsoulis L, Gehring R, Munro OQ van Heerden FR, Drewes SE. Venusol from Gunnera perpensa: structural and activity studies. Phytochemistry 2004; 65: 1117-1121

112 Guo L, Su J, Deng BW, Yu ZY, Kang LP, Zhao ZH, Shan YJ, Chen JP, Ma BP, Cong YW. Active pharmaceutical ingredients and mechanisms underlying phasic myometrial contractions stimulated with the saponin extract from Paris polyphylla Sm. var. yunnanensis used for abnormal uterine bleeding. Hum Reprod 2008; 23: 964-971

113 Promprom W, Kupittayanant P, Indrapichate K, Wray S, Kupittayanant $S$. The Effects of pomegranate seed extract and beta-sitosterol on rat uterine contractions. Reprod Sci 2010; 17: 288-296

114 Gran L. An oxytocic principle found in Oldenlandia affinis DC. Medd Nor Farm Selsk 1970; 12: 173-180

115 Gran $L$. On the effect of a polypeptide isolated from "Kalata-Kalata" (Oldenlandia affinis DC) on the oestrogen dominated uterus. Acta Pharmacol Toxicol (Copenh) 1973; 33: 400-408

116 Craik DJ, Daly NL, Bond T, Waine C. Plant cyclotides: A unique family of cyclic and knotted proteins that defines the cyclic cystine knot structural motif. J Mol Biol 1999; 294: 1327-1336

117 Colgrave ML, Craik DJ. Thermal, chemical, and enzymatic stability of the cyclotide kalata B1: the importance of the cyclic cystine knot. Biochemistry 2004; 43: 5965-5975

118 Gillon AD, Saska I, Jennings CV, Guarino RF, Craik DJ, Anderson MA. Biosynthesis of circular proteins in plants. Plant J 2008; 53: 505-515

119 Saska I, Gillon AD, Hatsugai N, Dietzgen RG, Hara-Nishimura I, Anderson MA, Craik DJ. An asparaginyl endopeptidase mediates in vivo protein backbone cyclization. J Biol Chem 2007; 282: 29721-29728
120 Gruber CW, Cemazar M, Clark RJ, Horibe T, Renda RF, Anderson MA Craik DJ. A novel plant protein disulfide isomerase involved in the oxidative folding of cystine knot defense proteins. J Biol Chem 2007; 282: 20435-20446

121 Gran L, Sletten K, Skjeldal L. Cyclic peptides from Oldenlandia affinis DC. Molecular and biological properties. Chem Biodivers 2008; 5: 2014-2022

122 Rosengren KJ, Daly NL, Plan MR, Waine C, Craik DJ. Twists, knots, and rings in proteins. Structural definition of the cyclotide framework. J Biol Chem 2003; 278: 8606-8616

123 Mulvenna JP, Sando L, Craik DJ. Processing of a $22 \mathrm{kDa}$ precursor protein to produce the circular protein tricyclon A. Structure 2005; 13 : 691-701

124 Gruber CW, Muttenthaler M, Freissmuth M. Ligand-based peptide design and combinatorial peptide libraries to target G-protein coupled receptors. Curr Pharm Des, advance online publication 5 August 2010; BSP/CPD/E-Pub/00142

125 Tyndall JD, Pfeiffer B, Abbenante G, Fairlie DP. Over one hundred peptide-activated $G$ protein-coupled receptors recognize ligands with turn structure. Chem Rev 2005; 105: 793-826

126 Schöpke T, Hasan Agha MI, Kraft R, Otto A, Hiller K. Hämolytisch aktive Komponenten aus Viola tricolor L. und Viola arvensis Murray. Sci Pharm 1993; 61: 145-153

127 Witherup KM, Bogusky MJ, Anderson PS, Ramjit H, Ransom RW, Wood T, Sardana M. Cyclopsychotride A, a biologically active, 31-residue cyclic peptide isolated from Psychotria longipes. J Nat Prod 1994; 57: 16191625

128 Gustafson KR, McKee TC, Bokesch HR. Anti-HIV cyclotides. Curr Protein Pept Sci 2004; 5: 331-340

129 Lindholm P, Göransson U, Johansson S, Claeson P, Gullbo J, Larsson R, Bohlin L, Backlund A. Cyclotides: a novel type of cytotoxic agents. Mol Cancer Ther 2002; 1: 365-369

130 Tam JP, Lu YA, Yang JL, Chiu KW. An unusual structural motif of antimicrobial peptides containing end-to-end macrocycle and cystine-knot disulfides. Proc Natl Acad Sci USA 1999; 96: 8913-8918

131 Göransson U, Sjogren M, Svangard E, Claeson P, Bohlin L. Reversible antifouling effect of the cyclotide cycloviolacin 02 against barnacles. J Nat Prod 2004; 67: 1287-1290

132 Colgrave ML, Kotze AC, Huang YH, O'Grady J, Simonsen SM, Craik DJ. Cyclotides: natural, circular plant peptides that possess significant activity against gastrointestinal nematode parasites of sheep. Biochemistry 2008; 47: 5581-5589

133 Barbeta BL, Marshall AT, Gillon AD, Craik DJ, Anderson MA. Plant cyclotides disrupt epithelial cells in the midgut of lepidopteran larvae. Proc Natl Acad Sci USA 2008; 105: 1221-1225

134 Gruber CW, Cemazar M, Anderson MA, Craik DJ. Insecticidal plant cyclotides and related cystine knot toxins. Toxicon 2007; 49: 561-575

135 Simonsen SM, Sando L, Ireland DC, Colgrave ML, Bharathi R, Goransson $U$, Craik DJ. A continent of plant defense peptide diversity: cyclotides in Australian Hybanthus (Violaceae). Plant Cell 2005; 17: 3176-3189

136 Gruber CW, Elliott AG, Ireland DC, Delprete PG, Dessein S, Goransson $U$, Trabi M, Wang CK, Kinghorn AB, Robbrecht E, Craik DJ. Distribution and evolution of circular miniproteins in flowering plants. Plant Cell 2008; 20: 2471-2483

137 Mulvenna JP, Mylne JS, Bharathi R, Burton RA, Shirley NJ, Fincher GB, Anderson MA, Craik DJ. Discovery of cyclotide-like protein sequences in graminaceous crop plants: ancestral precursors of circular proteins? Plant Cell 2006; 18: 2134-2144

138 Trabi M, Svangard E, Herrmann A, Goransson U, Claeson P, Craik DJ, Bohlin $L$. Variations in cyclotide expression in viola species. J Nat Prod 2004; 67: 806-810

139 Seydel P, Gruber CW, Craik DJ, Dörnenburg H. Formation of cyclotides and variations in cyclotide expression in Oldenlandia affinis suspension cultures. Appl Microbiol Biotechnol 2007; 77: 275-284

140 Clark RJ, Daly NL, Craik DJ. Structural plasticity of the cyclic-cystineknot framework: implications for biological activity and drug design. Biochem J 2006; 394: 85-93

141 Gunasekera S, Daly NL, Anderson MA, Craik DJ. Chemical synthesis and biosynthesis of the cyclotide family of circular proteins. IUBMB Life 2006; 58: 515-524

142 Thongyoo P, Bonomelli C, Leatherbarrow RJ, Tate EW. Potent inhibitors of beta-tryptase and human leukocyte elastase based on the MCoTI-Il scaffold. J Med Chem 2009; 52: 6197-6200 
143 Gruber CW. Global cyclotide adventure: a journey dedicated to the discovery of circular peptides from flowering plants. Biopolymers, advance online publication 26 May 2010; DOI: 10.1002/bip.21414

144 Craik DJ. Seamless proteins tie up their loose ends. Science 2006; 311 : 1563-1564

145 Craik DJ, Cemazar M, Daly NL. The cyclotides and related macrocyclic peptides as scaffolds in drug design. Curr Opin Drug Discov Devel 2006; 9: 251-260

146 Craik DJ, Clark RJ, Daly NL. Potential therapeutic applications of the cyclotides and related cystine knot mini-proteins. Expert Opin Investig Drugs 2007; 16: 595-604

147 Uguru MO, Ekwenchi MM, Evans F. Bioassay-directed isolation of oxytocic principles from the methanol extract of Monechma ciliatum. Phytother Res 1999; 13: 696-699

148 Nworu CS, Akah PA, Okoli CO, Okoye TC. Oxytocic activity of leaf extract of Spondias mombin. Pharm Biol 2007; 45: 366-371

149 Falodun A, Nworgu ZA, Ikponmwonsa MO. Phytochemical components of Hunteria umbellata (K. Schum) and its effect on isolated non-pregnant rat uterus in oestrus. Pak J Pharm Sci 2006; 19: 256-258

150 Kamatenesi-Mugisha M, Makawiti DW, Oryem-Origa H, Olwa O, Nganga J. The oxytocic properties of Luffa cylindrica (L.) M. Roem. and Bidens pilosa L., traditionally used medicinal plants from western Uganda. Afr J Ecol 2007; 45: 88-93

151 Kamanyi A, Djikeng A, Bopelet M. Dry seeds of Momordica foetida (Cucurbitaceae) Schum. demonstrate potential antiimplantation and uterotenoic effects. Rev Med Pharmacol Africa 1997; 11-12: 17-26

152 Chen $M-X$, Chu $Y-H$. Effect of radix trichosanthis on uterine contraction in pseudopregnant rabbits. Chin J Pharm 1993; 24: 257-260

153 Kamatenesi-Mugisha M, Oryem-Origa H. Medicinal plants used to induce labour during childbirth in western Uganda. J Ethnopharmacol 2007; 109: 1-9

154 Slattery MM, Morrison JJ. Preterm delivery. Lancet 2002; 360: 14891497

155 World Health Organisation. The world health report 2005. Available at http://www.who.int/whr/2005/en/index.html. Accessed July 26, 2010

156 Howson CP, Merialdi M, Lawn JE, Requejo JH, Say L. March of Dimes white paper on preterm birth. Available at http://marchofdimes.com. Accessed July 26, 2010

157 Lawn JE, Cousens S, Zupan J. 4 million neonatal deaths: when? where? why? Lancet 2005; 365: 891-900

158 PeriStats. March of Dimes online database 2006. Available at http:// www.marchofdimes.com/peristats. Accessed July 26, 2010

159 Mozurkewich E, Chilimigras J, Koepke E, Keeton K, King VI. Indications for induction of labour: a best-evidence review. BJOG 2009; 116: 626636

160 Chong YS, Su LL, Arulkumaran S. Current strategies for the prevention of postpartum haemorrhage in the third stage of labour. Curr Opin Obstet Gynecol 2004; 16: 143-150

161 Nordstrom L, Fogelstam K, Fridman G, Larsson A, Rydhstroem H. Routine oxytocin in the third stage of labour: A placebo controlled randomised trial. Br J Obstet Gynaecol 1997; 104: 781-786

162 Gulmezoglu AM, Forna F, Villar J, Hofmeyr GJ. Prostaglandins for prevention of postpartum haemorrhage. Cochrane Database Syst Rev 2004; 3: CD000494

163 Sinei KA, Mwangi JW. Effect of the tuber of Adenia globosa on isolated rat uterus preparation. Int J Pharmacognosy 1995; 33: 346-347

164 Veale DJH, Havlik I, Oliver DW, Dekker TG. Pharmacological effects of Agapanthus africanus on the isolated rat uterus. J Ethnopharmacol 1999; 66: 257-262

165 Page JE, Balza F, Nishida T, Towers GHN. Biologically-active diterpenes from Aspilia mossambicensis, a Chimpanzee medicinal plant. Phytochemistry 1992; 31: 3437-3439

166 Donaldson VH. Serotonin-like activity in bamboo extracts. Lancet 1982; $1: 166$

167 Chagnon MJ. General pharmacological inventory of medicinal plants of Rwanda. J Ethnopharmacol 1984; 123: 239-251

168 Corallo A, Savineau JP, Tricoche R, Foungbe S. The uterotonic action of the aqueous extract of Bridelia atroviridis in the rat. Fundam Clin Pharmacol 1991; 5: 319-329

169 Amos S, Binda L, Kunle OF, Wambebe C, Gamaniel K. Uterotonic properties of the ethanol extract of Brysocarpus coccineus. Pharm Biol 2002; 40: 33-38

170 Adebiyi A, Adaikan PG, Prasad RNV. Papaya (Carica papaya) consumption is unsafe in pregnancy: fact or fable? Scientific evaluation of a common belief in some parts of Asia using a rat model. Br J Nutr 2002; 88: 199-203

171 Piyachaturawat P, Glinsukon T, Chanjarunee A. Antifertility effect of Citrus hystrix DC. J Ethnopharmacol 1985; 13: 105-110

172 Eno AE, Itam EH. Stimulation of autonomic cholinoceptors in the rat uterus by a crude extract from Eleophorbia drupifera leaves. Pharm Biol 1998; 36: 97-102

173 Monga M, Weisbrodt NW, Andres RL, Sanborn BM. The acute effect of cocaine exposure on pregnant human myometrial contractile activity. Am J Obstet Gynecol 1993; 169: 782-785

174 Karalai C, Wiriyachitra P, Sorg B, Hecker E. Medicinal plants of Euphorbiaceae occuring and utilized in Thailand. 5. Skin irritants of the daphnane and tigliane type in latex of Excoecaria bicolor and the uterotonic activity of the leaves of the tree. Phytother Res 1995; 9: 482488

175 Bafor EE, Omogbai EKI, Ozolua RI. In vitro determination of the uterine stimulatory effect of the aqueous leaf extract of Ficus exasperata. J Ethnopharmacol 2010; 127: 502-507

176 Ie 0, Zam N. Oxytocic properties of the aqueous extract of Globimetula braunii (Loranthaceae). Pak J Pharm Sci 2008; 21: 356-360

177 Kaido TL, Veale DJH, Havlik I, Rama DBK. Preliminary screening of plants used in South Africa as traditional herbal remedies during pregnancy and labour. J Ethnopharmacol 1997; 55: 185-191

178 Mahomed IM, Ojewole JAO. Uterotonic effect of Harpagophytum procumbens DC (Pedaliaceae) secondary root aqueous extract on rat isolated uterine horns. J Smooth Muscle Res 2009; 45: 231-239

179 Katerere D, Parry 0 . Pharmacological actions of Heteromorpha trifoliata ("dombwe") on rat isolated muscle preparations. Cent Afr J Med 2000; 46: 9-13

180 Chen ZS, Chen CX, Kwan CY. Leonurine, an alkaloid from Leonurus artemesia, induces contraction in mouse uterine smooth muscle but relaxation in vascular smooth muscle of rat portal vein. Biomed Res (Aligarh) 2000; 11: 209-212

181 Yeung HW, Kong YC, Lay WP, Cheng KF. The structure and biological effect of leonurine a uterotonic principle from the Chinese drug I-MU-TS'AO. Planta Med 1977; 31: 51-56

182 Ayinde BA, Onwukaeme DN, Nworgu ZAM. Oxytocic effects of the water extract of Musanga cecropioides R. Brown (Moraceae) stem bark. Afr J Biotechnol 2006; 5: 1350-1354

183 Bafor E, Sanni U. Uterine contractile effects of the aqueous and ethanol leaf extracts of Newbouldia laevis (Bignoniaceae) in vitro. Indian J Pharm Sci 2009; 71: 124-127

184 Datte J, Offoumou AM, Manda OM. Uterotonic effects of hydromethanolic extract of Parquetina nigrescens (Periplocaceae) on spontaneous contractile activity in the isolated myometrium of pregnant rats. J Ethnopharmacol 1996; 53: 15-20

185 Oluwole FS, Bolarinwa AF. The uterine contractile effect of Petiveria alliacea seeds. Fitoterapia 1998; 69: 3-6

186 Udoh FV. Uterine muscle reactivity to repeated administration and phytochemistry of the leaf and seed extracts of Piper guineense. Phytother Res 1999; 13: 55-58

187 Arteche E, Strippoli G, Loirand G, Pacaud P, Candenas L, Molto JC, Souto L, Fernandez J, Norte M, Martin JD, Savineau JP. An analysis of the mechanisms involved in the okadaic acid-induced contraction of the estrogen-primed rat uterus. J Pharmacol Exp Ther 1997; 282: 201207

188 Katsoulis LC, Veale DJ, Havlik I. The pharmacological action of Rhoicissus tridentata on isolated rat uterus and ileum. Phytother Res 2000; 14: 460-462

189 Panossian A, Wikman G. Pharmacology of Schisandra chinensis Bail.: An overview of Russian research and uses in medicine. J Ethnopharmacol 2008; 118: 183-212

190 Sanchez LM, Bulnes C, Perez P, Rodriguez A, Noa M, Ginorio C, Gomez BC. Antibacterial, wound healing and isolated uterus activity of Solanum americanum Miller. Actual Biol (Medellin) 2003; 25: 71-78

191 Ladeji O, Udoh FV, Okoye ZSC. Activity of aqueous extract of the bark of Vitex doniana on uterine muscle response to drugs. Phytother Res 2005; 19: 804-806

192 Misra MB, Mishra SS, Misra RK. Screening of a few indigenous abortifacients. J Indian Med Assoc 1969; 52: 535

$193 \mathrm{Ng}$ TB, Wong RNS, Yeung HW. 2 proteins with ribosome-inactivating, cytotoxic and abortifacient activities from seeds of Luffa cylindrica Roem (Cucurbitaceae). Biochem Int 1992; 27: 197-207

194 Chase MW, Reveal JL. A phylogenetic classification of the land plants to accompany APG III. Bot J Linn Soc 2009; 161: 122-127 